\title{
An Investigation into the Relationship Between Social Capital and Built Environment of Residential Neighborhoods with an Emphasis on Public and Open Spaces: A Case Study of Tabriz
}

\author{
Mohammad Soltanzadeh Zarandi* \\ Assistant Professor, Faculty of Art \& Architecture, Bahonar University, Kerman, Iran. \\ (Received 3 Jan 2020, Accepted 4 May 2020)
}

Residential neighborhoods face challenges and anomalies in terms of their social aspect and the research upon various fields is aimed to find solutions to reduce or deal with them. Architectural and urban designers attempt to contribute to the promotion of social environment in neighborhoods and provide patterns, recommendations or policies in the scope of residence with regard to the concepts suggested in sociology, psychology and so on. Social capital is one of the notable concepts that have been proposed in recent decades. Social capital considers the resources available in the relationships of the individuals and groups and regards the resources as a capital for advancing the individual and collective goals. In the present century, it has been proposed as an option to confront the social challenges of human settlements in the form of communities and neighborhoods. Concepts such as social capital help designers to obtain a clearer picture of what is happening in communities and neighborhoods and to provide the physical solutions. This research seeks to explore the relationship between the built environment of residential communities (focusing on open and public spaces) and the social capital and to find components or criteria of the built environment associated with the social capital. Due to the diversity and multiplicity existing in the definition of the concept, this study introduces a certain framework and determines five components including the trust, reciprocity, place attachment, local participation, and neighborhood ties to evaluate this concept. It also describes some components for assessing the built environment in two aspects of physical structure of community and physical components, and develops the research model. This model is tested in two case studies in Tabriz, Iran, which are physically different. To achieve the goal, this study employs a combination of data (triangulation method) derived from survey, observations and ob- jective structure of samples, and states that the built environment has a definite but minor effect on the social capital of inhabitants. The results showed that although the physical criteria of the two communities are different, especially in terms of the components contributing to the social capital as considered in the previous research, the level of social capital of the residents in the two samples and their assessment of the residential environment are close to each other. As the research suggests, it cannot be expected that the change in the built environment creates a balanced change in the behavior patterns of the residents. Beyond this general and remarkable result, the analyses showed that all the physical components affecting the social capital reviewed in the West do not appear to be true in the context of Iran. Also, among the physical criteria, the open space surface and the sidewalk surface are more strongly correlated with the social capital than the density. The most effective action for influencing the social capital through the change or modification of the physical structure is to predict the public green space (local parks), and among the influential components, the attractiveness of open and public spaces has the strongest relationship with the social capital of the residents. In general, this research states that it is necessary for refining, designing or improving the built environment of residential communities to avoid the direct referral to the Western studies and the mere reliance on their results and to involve the (social) considerations of the context of Iran. However, this requires extensive research to gain a proper understanding of the relationship between the social and built environment of the communities in the current Iranian society.

Keywords: Social Capital, Built Environment, Public and Open Spaces, Neighborhood.

\footnotetext{
*Corresponding author. E-mail: msoltan@uk.ac.ir
} 
برر سى رابطةُ سرمايه اجتماعى و محيط كالبدى محلات

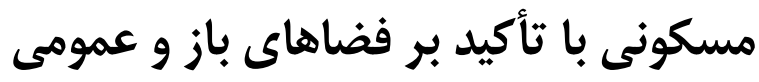
(نمونهُ موردى: دو محله متعلق به شهر تبريز)

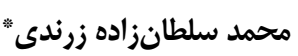

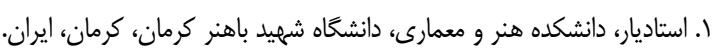

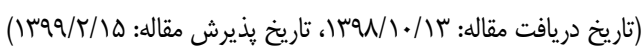

محلات مسكونى با جالشها و ناهنجارىهايى در وجه اجتماعى خود روبهرو هستند و طراحان در حوزهٔ معمارى و

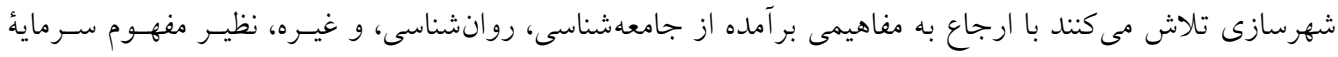

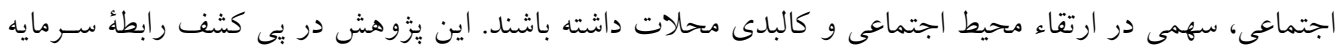

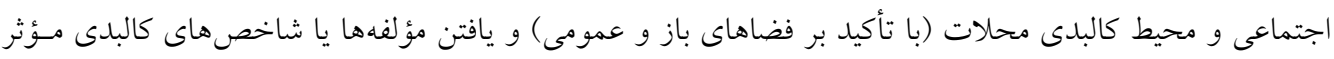

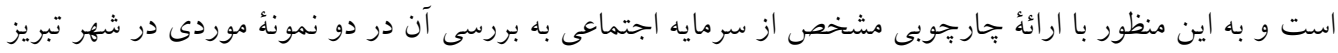

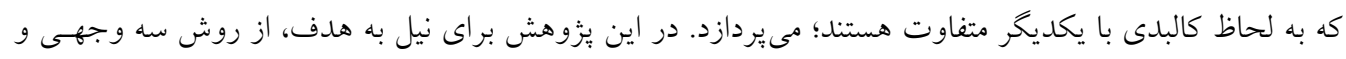

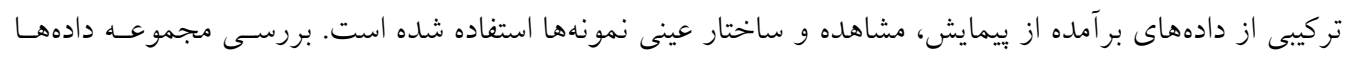

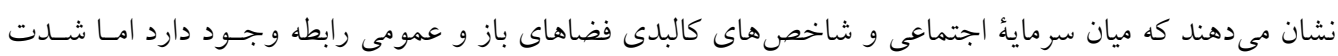

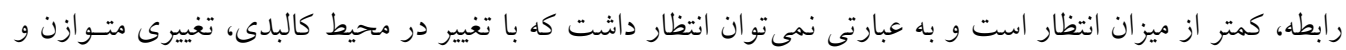

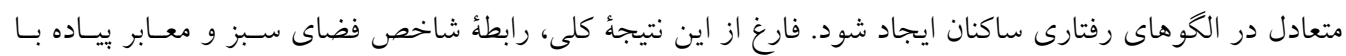

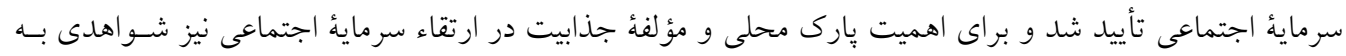




\section{مقدمه}

فردى، محلى و جامعه قابل طـرح هسـتند. سـرمايةُ اجتمـاعى مز ايا و آوردههايى براى دارندكان آن (فرد و محله) بـه همـــــاه

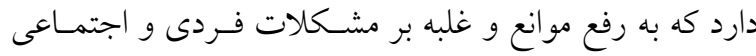
كمك مى كند و به همين دليل در بسيارى از كشورهاى ييشرو

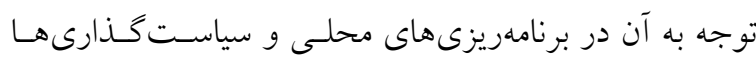
مفيد و ضرورى دانسته شده است. در سوى ديخر، همسو با افزايش توجهى كه نسـبت بـهـ

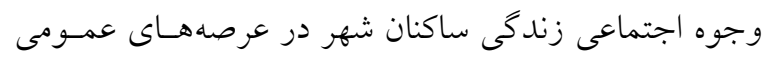

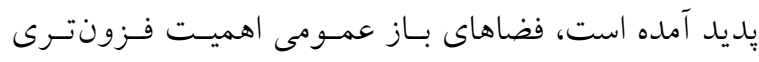

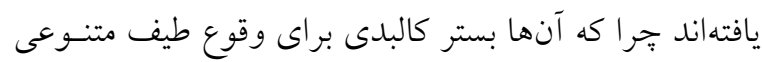

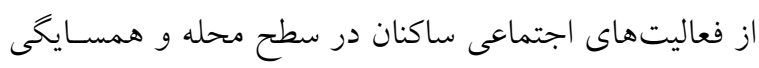

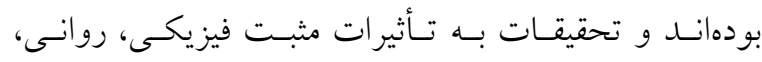

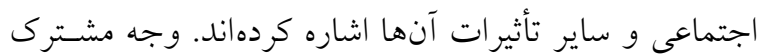

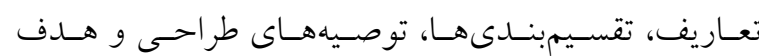
كذارىهاى مختلفى كه براى اين فضـاها بيـان شــه، تـأمين

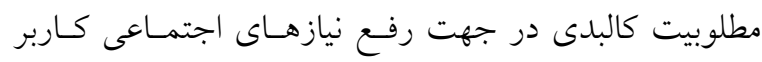

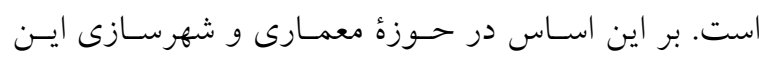

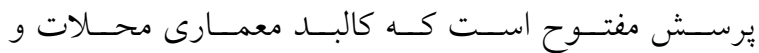

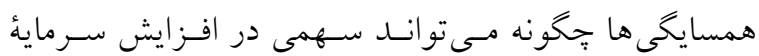

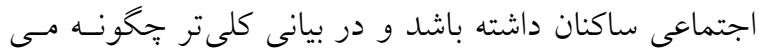
توان از طريق طر احى همسايخى هـا، زمينـأ بهبـود و ارتقـاء محيط اجتماعى را فراهم كرد. از آنجا كه ايران در كنار روند

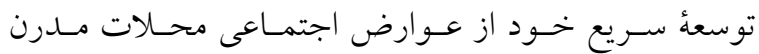

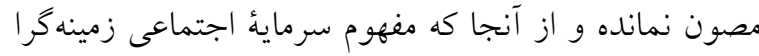

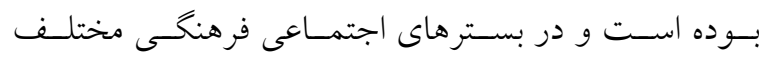
نمودهاى متفاوتى دارد، اين يزّوهش تلاش مى كند تا وجـود

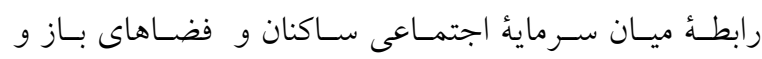

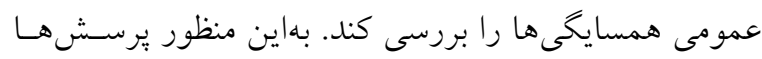

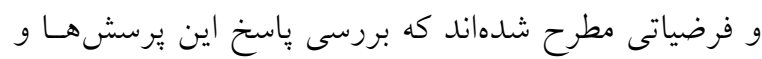

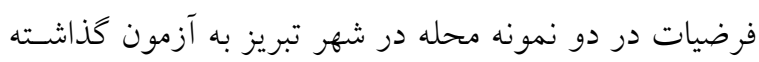
مىشوند. - ميات

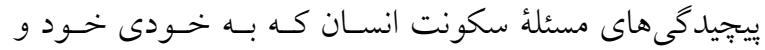

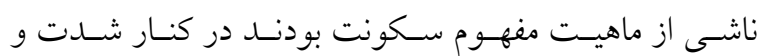
سرعت تغييرات برآمده از عصر مدرن، سبب شدند تـا انسـان

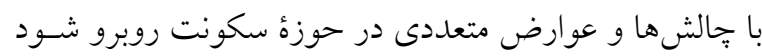

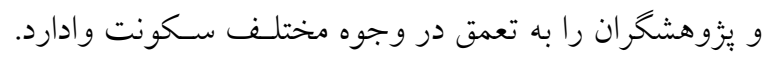

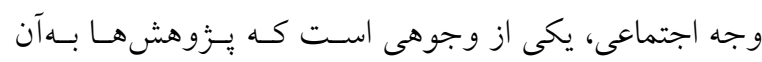

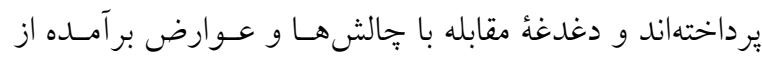

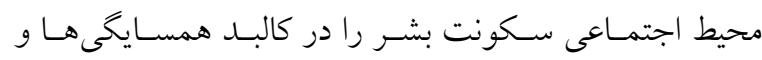

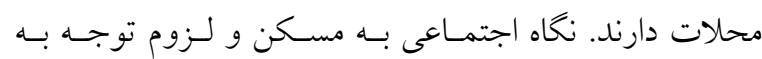

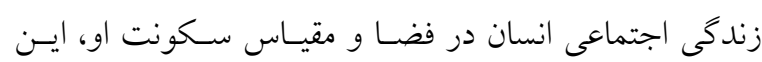

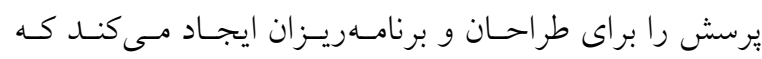

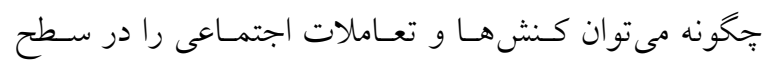

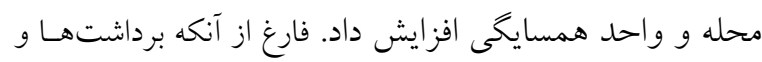

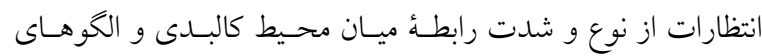
رفتارى انسان در قالب نظريات و رويكردهاى مختلف، تفاوتهايى

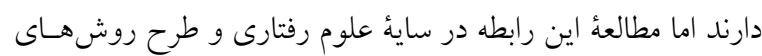

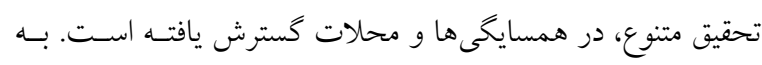

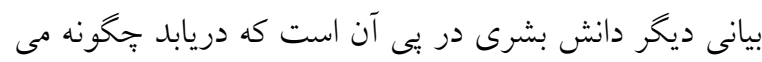

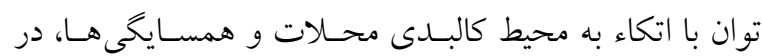

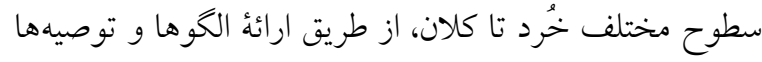

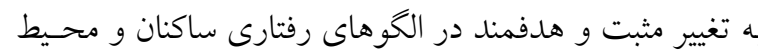

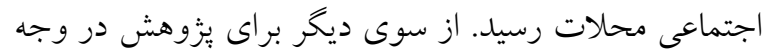
اجتماعى محلات، حوزههايى همجيـون جامعسهشناسى، روان

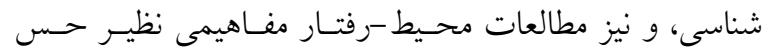

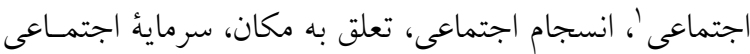

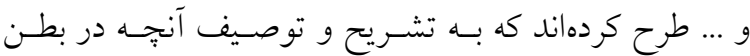

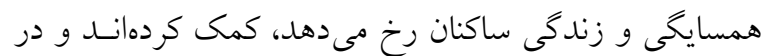
نتيجه مى توانند براى رفع مشكلات، راهكارهايى ارائسه كنـــــ

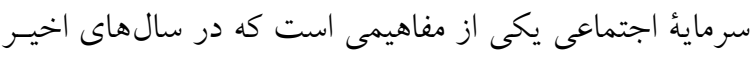

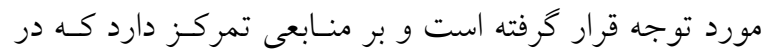

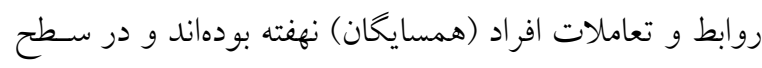


بررسى رابطة سرمايه اجتماعى و محيط كالبدى محلات مسكونى با تأكيد بر فضاهاى باز و عمو مى

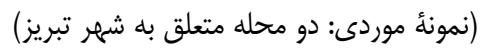

اجتماعى اقتصادى (سن، جنسيت، وضعيت اشـتغال و تأهـل،

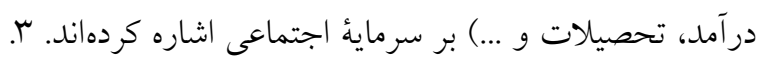
بررسى رابطهُ محيط ساخته شده (محسيط كالبـدى) و سـرمائ

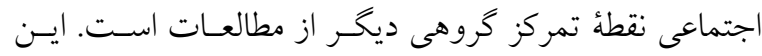

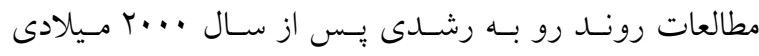

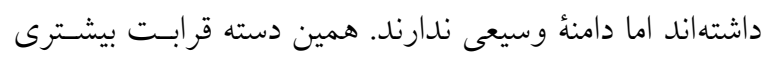

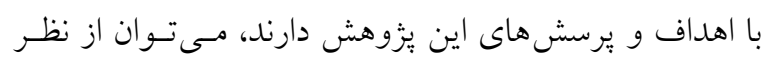

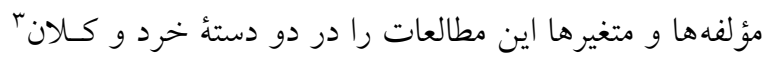
جاى داد (جدول (). الف: برخى مطالعـات در ايسن دسته بـهـ

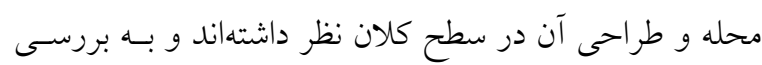

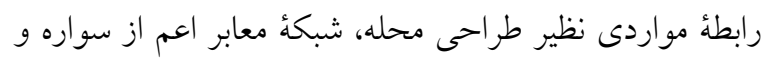

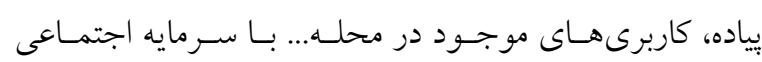

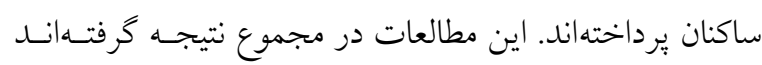

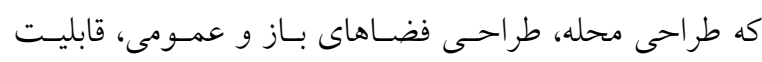

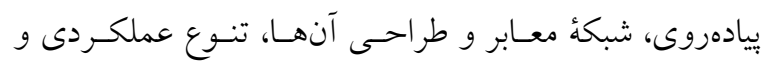

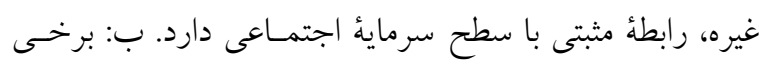

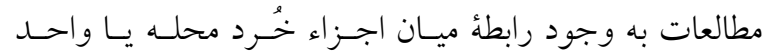

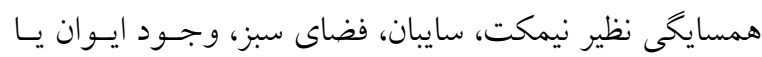
تراس و ... با ميزان سرمائأ اجتماعى ساكنان اشـاره دارنـــ. بــهـ

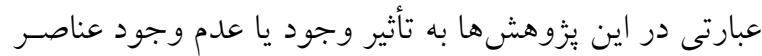

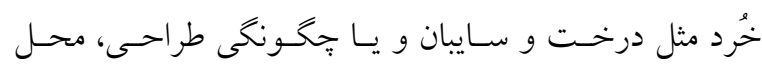

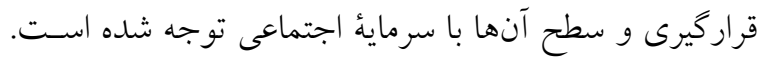

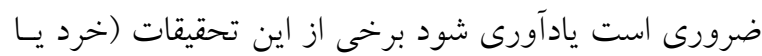

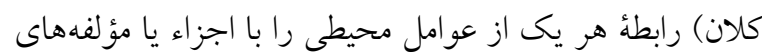

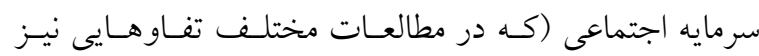
دارند) بررسى كردهاند و برخى، سرمايه اجتماعى را به عنسوان

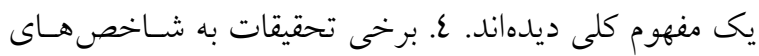

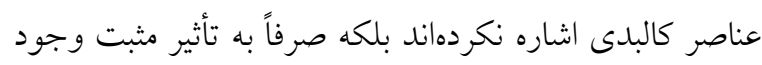

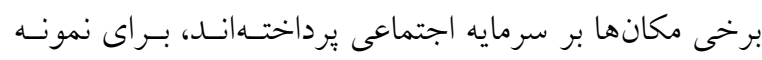

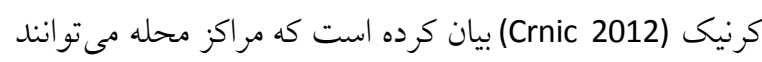

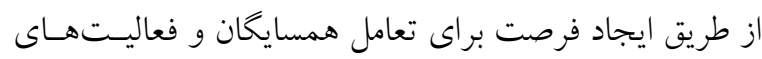
مدنى بر سرمائُ اجتماعى مؤثر باشند. كاتسل (Cattell 2001)

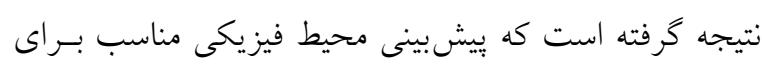

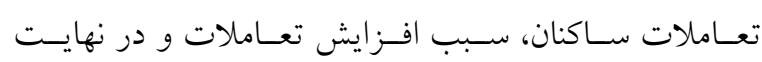

\section{(. اهداف و يرسشها}

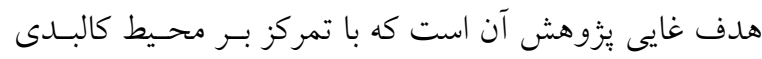

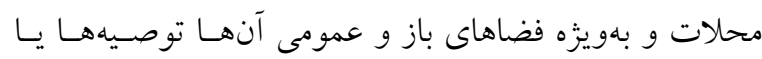

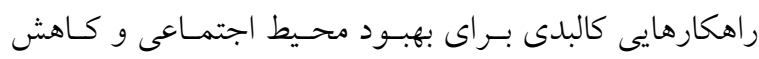

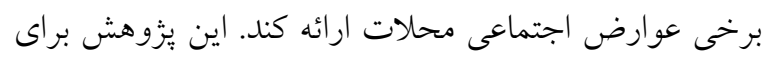

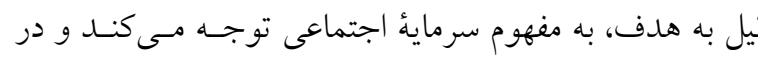

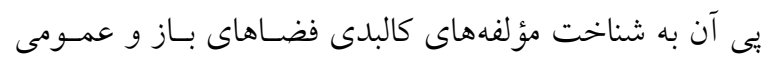

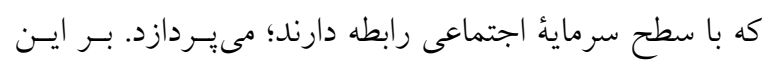

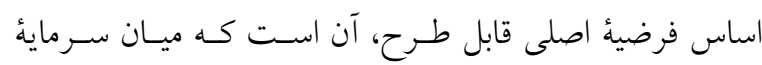

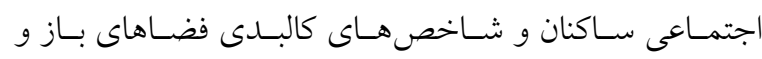

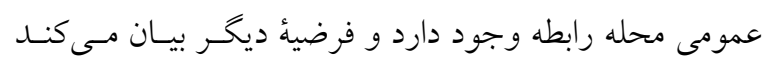

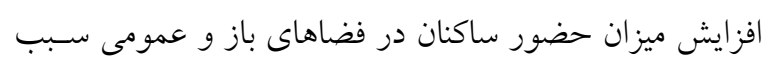

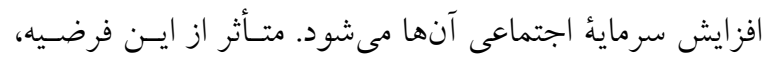

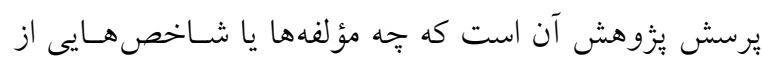

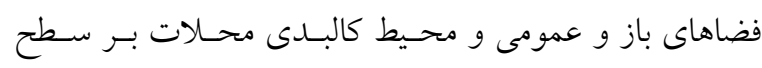
سرمائُ اجتماعى (يا مؤلفههاى آن) و ميزان حضور و سـاكنان

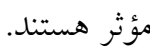

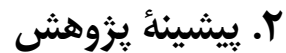

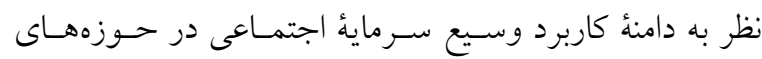

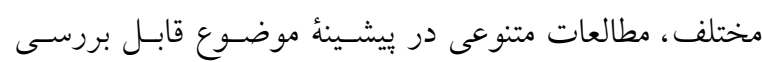

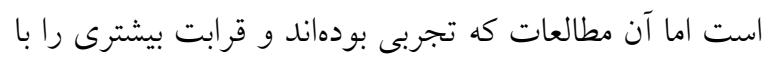

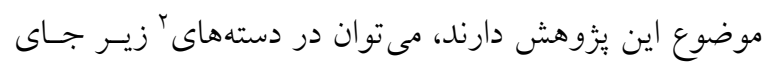

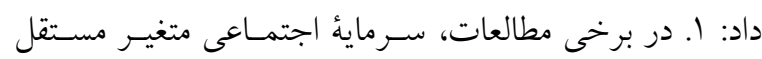

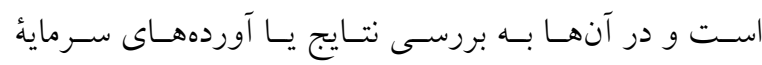

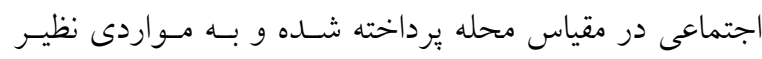

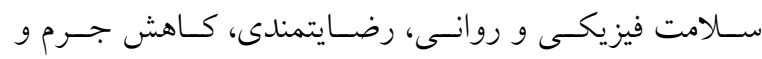

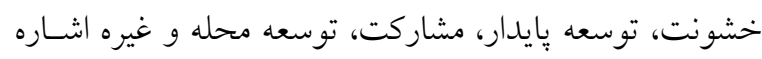

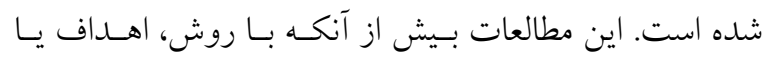

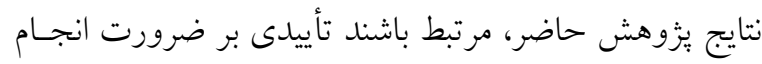
آن هستند. ז. دستئ ديخرى از مطالعات به عواملى توجه دارند

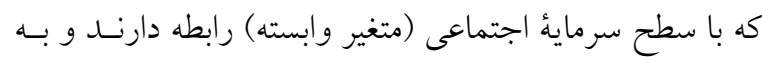

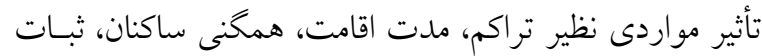

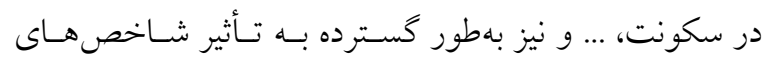


جدول (: خلاصهاى از ييشينه موضوع با محوريت محيط كالبدى

Table1: Summary of Studies on Social Capital

\begin{tabular}{|c|c|c|c|c|}
\hline \multicolumn{2}{|c|}{ سرمايه اجتماعى } & \multirow{2}{*}{ مولفه، متغير } & \multirow{2}{*}{ يزوهش } & \\
\hline اجزاء مفهوم & كليت مفهوم & & & \\
\hline & * & ي يياده محور، اختلاط عملكردى & (Leyden 2003) & \multirow{7}{*}{ 安 } \\
\hline & * & ميياده محور & (Rogers et al. 2010) & \\
\hline \multirow[t]{4}{*}{ اعتماد، مشاركت اجتماعى } & & طراحى همسايكى، طرحبندى خيابانها، و زيبايى & (Wood 2006) & \\
\hline & * & طراحى محله بر اساس تئورىهاى نوين شهرسازى & (Cabrera 2013) & \\
\hline & & طراحى فضاهاى باز و عمومى & (Kang 2006) & \\
\hline & * & طرح محله (به عنوان يك كل) & $\begin{array}{c}\text { (Subramanian, Lochner and } \\
\text { Kawachi 2003) }\end{array}$ & \\
\hline \multirow[t]{2}{*}{ اعتماد، تعامل، مشاركت } & & طراحى محله، يياده محور & (Wood, Corti and Bulsara 2012) & \\
\hline & * & 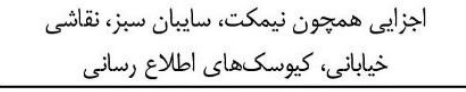 & (Semenza and March 2009) & \multirow{5}{*}{$\ddot{\imath}}$. \\
\hline \multirow[t]{2}{*}{ اعتماد، مشاركت اجتماعى } & & خدمات و تسهيلات محلى (تنوع كاربرى) & (Wood 2006) & \\
\hline & $*$ & وجود درخت و سايبان سبز & $\begin{array}{l}\text { (Holtan, Dieterlen and Sullivan } \\
\text { 2014) } \\
\end{array}$ & \\
\hline \multirow[t]{2}{*}{ اعتماد، مشاركت مدنى, تعامل } & & نظافت و تميزى همسايگى & (Wood et al. 2008) & \\
\hline & $*$ & فضاى سبز، درخت & (Vemuri et al. 2011) & \\
\hline
\end{tabular}

آنها شـامل جنبـهاى از يـك سـاخت اجتمـاعى بـودهانـد، و كنشهاى افراد را تسهيل مى كنند (Coleman 2006) · بورديسو آن رادر كنار سرمائ فرهنكى، اقتصادى، و نمـادين در نظريـهُ خود جاى داده (Bourdieu 1985) و از ديد بِاتنـام ( Putnam

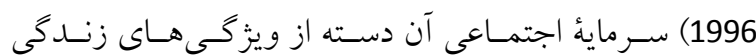

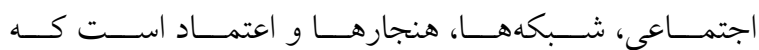
مشاركت كنندگان را قادر مى سازد تا به شيوهاى مؤثرتر اهداف مشترك خود را تعقيب كنند. به بيانى ساده، بر اسـاس مفهـوم

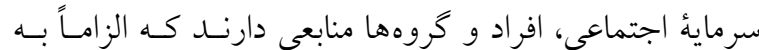

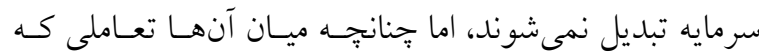
كيفيت و كميت لازم را داشته باشد، رخ دهد؛ آنگاه منـابع بـهـ سرمايه تبديل مىشوند و در اختيار فرد يا گروه قرار مى گيرند و مى توانند از اين سرمايه (همجيجون ديخر انواع سرمايه) بـراى يشيشبرد اهداف و غلبه بر موانـع اسـتفاده كنتـد. تبيسين مزايـا و كاركرد سرمائه اجتماعى سبب شد تا تمايل روزافزونى به اين مفهوم در حوزهٌ سكونت و طراحى محلات ايجـاد شـود، بـهـ كونهاى كه از بيش از دو دهأ قبل حمايت از سرمايه اجتماعى

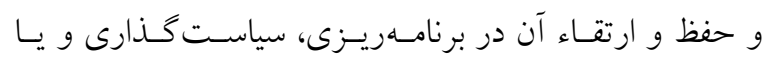
توصيه هايى كه براى توسعه يا بهبود محلات ارائسه مسىشـود،

$$
\text { شكل گيرى سرمائُ اجتماعى مىشود. }
$$

در مجمـوع، مطالعـات (بـهويـرزه گـروه دو تـا جهـار) شواهدى را براى وجود رابطه ميان محيط كالبدى و سـرمائ

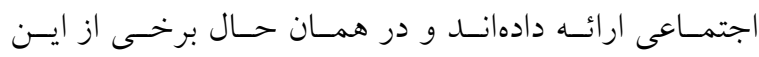
مطالعات اشاره كردهاند كه محيط كالبدى نمى تواند مسـتقيماً سرمايه اجتمـاعى را خلـق كنــ، امـا مسى توانــ موقعيـت و و فرصتهايى را براى ملاقات و تعامل افراد ايجاد كند.

\section{"ا. مبانى نظرى يزوهثى}

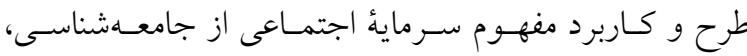

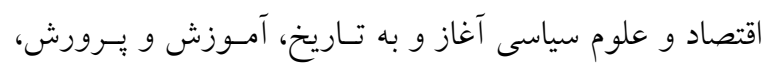

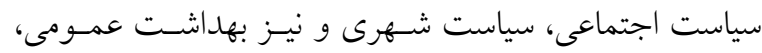
طر احى شهرى، معمارى، يزشكى و مديريت گسـترش يافـت (Field 2006 , Fukuyama 1997) جاكوبز (Jacobs 1992) در حوزهُ طراحى شهرى و در ياسـخ به معضلات اجتماعى محلات مسكونى طرح شد امـا تعـاريف اصلى و مركزى آن توسط ياتنام، كلمن و بورديسو بيـان شــده است. سرمائة اجتماعى شيئى واحد نيست، بلكـه داراى انـواع

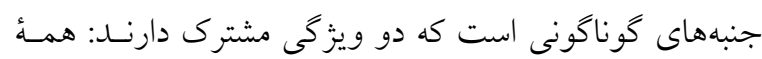


بررسى رابطأ سرمايه اجتماعى و محيط كالبدى محلات مسكونى با تأكيد بر فضاهاى باز و عمو مى

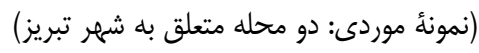

و ساختارى در نظر مى گيرد.

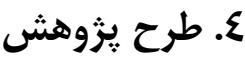

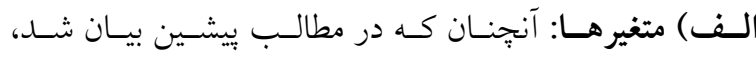
تحقيقات بر اساس اهداف و رويكردهـاى خــود مؤلفـهـــاى مختلفى را براى سنجش سرمائُ اجتماعى طرح كردهانـد، ايسن يزّوهش براى سنجش متغير وابسته يعنى سـرمايه اجتمـاعى و

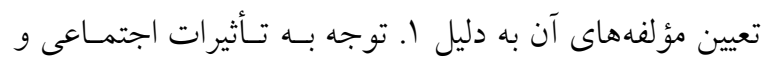

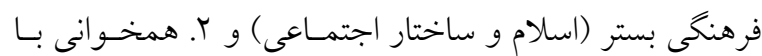

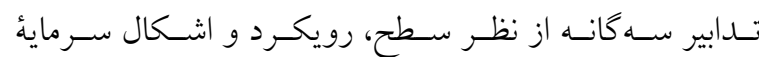

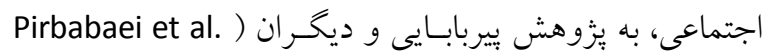
2016) و نظر به وجود متغير محيط كالبدى به يزوهش بركينز

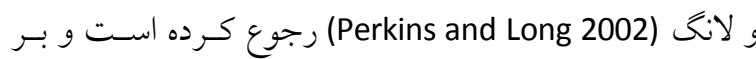
اين اساس ينج مؤلفه براى سرمائُ اجتماعى درنظر مسى كيـرد:

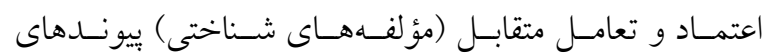

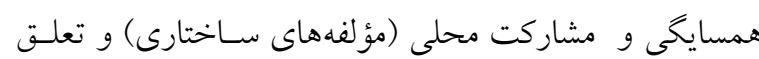

به محله.

سنجش محيط ساخته شده (متغيـر مستقل) در دو وجـهـ

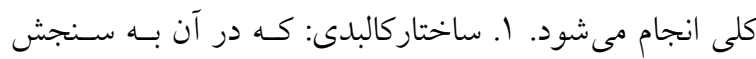
مواردى جون تراكم واحـدهاى مسـكونى از نظـر مسـاحت و

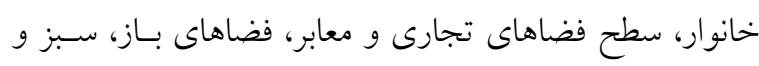
غيره در سطح محلـه برداختـهـ مسىشـود. ايسن امـر از طريـق نقشههاى موجود شهرى و نيـز خـردآورى اطلاعـات ميـانى صورت مى گيرد. r. اجزاء كالبدى: بررسى تحقيقـاتى كـه بـهـ

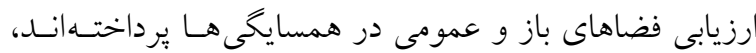
براى رسيدن به نتايجى دقيقتـر دو توصسيه داشـتهانــا: انجـام ارزيابى ادراكى سـاكنان ) French et al. 2014; Koohsari et Gehl and Svarre (al. 2015 و استفاده از تركيبى از روشها (a)

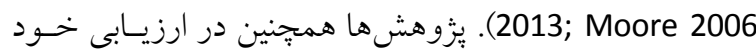
مؤلفه هايى جون موقعيت، فاصله، ابعاد، جذابيت، تسـيلات و : تجهيزات فضـاهاى بــاز عمـومى را لحـاظ كـردهانـــ. برخسى تحقيقـات (Koohsari et al. 2015) نيـز بيـان كـدمهانـد كـه رايجترين مؤلفهها فاصله، ابعـاد، و جــابيت هسـتند. بـر ايسن اساس براى سنجش اجزاء كالبدى همسـايكى، مؤلفـهــاى ا.
جايخـاهى مهـم و مؤكســـ يافتـه اسـت ) Barton et al 2003;

.(Forrest and Keans 2001

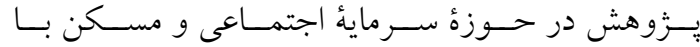
دشوارىهايى روبرو است. بـراى سـرمايةُ اجتمـاعى تعـاريف

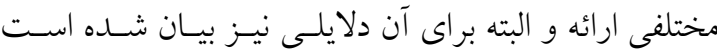

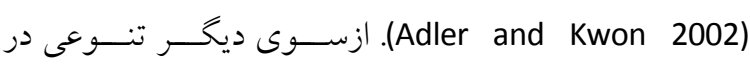

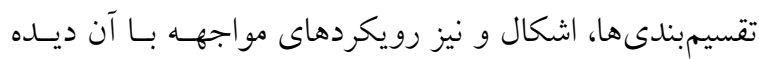
مىشود كه لازم است در امر يزوهش بدان توجه شود. بر ايسن

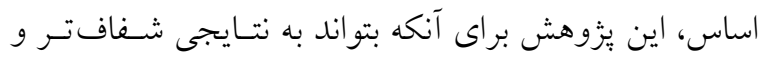

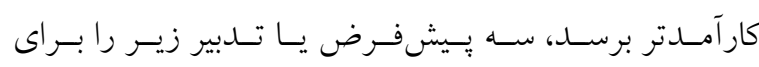
شكل گيرى مبانى تحقيق لحاظ مى كند:

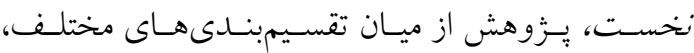
سـرمائة اجتمـاعى را در دو شـكل (اسـاختارى)" و (شــاختى)" بررسى مى كند. سرمائُ اجتماعى ساختارى، جنبـهـــاى عينى

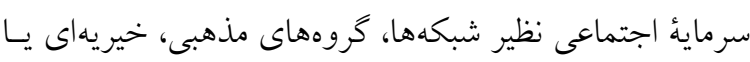
داوطلبـى و ... را شـامل مسىشـود و سـاختار خــارجى قابـل مشاهدهاى دارد. سرماية اجتماعى شناختى ناشسى از فراينـدى ذهنى است و شامل هنجارها، ارزشها، نخرشها و اعتقـاداتى

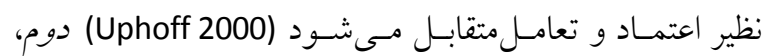
سرمائ اجتماعى در سه سطح خرد (بستخان، دوستان) ميـانى (كروههاى غيررسمى، همسايخان، محلـه) كـلان (كـروههـاى رسمى، جامعسه) بـروز مسى كنــ ( Grootaert and Bastelaer 2002). اين بزوهش به سطح خرد و ميـانى نظـر دارد. سـوم، رويكردهاى مختلفى در مطالعهُ سرمائة اجتماعى وجود دارند، رويكرد نخست كه به رويكرد اين بززوهش نزديكتر است بـه

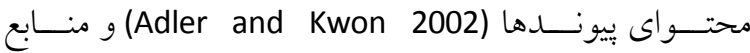
و و به بيانى ساده به افــراد توجه دارد و بدين مى يردازد كه جگگونه افراد به منابع نهفته در شبكههاى اجتماعى دسترسى مى يابند و از آن استفاده مى كنتـد

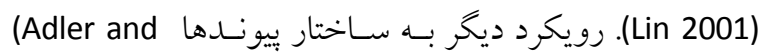

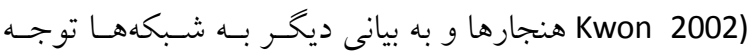

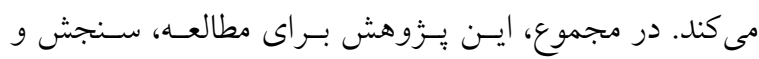

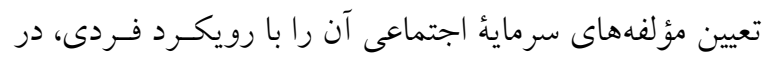

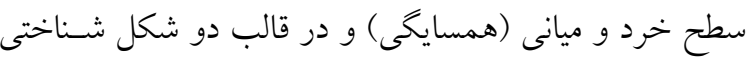




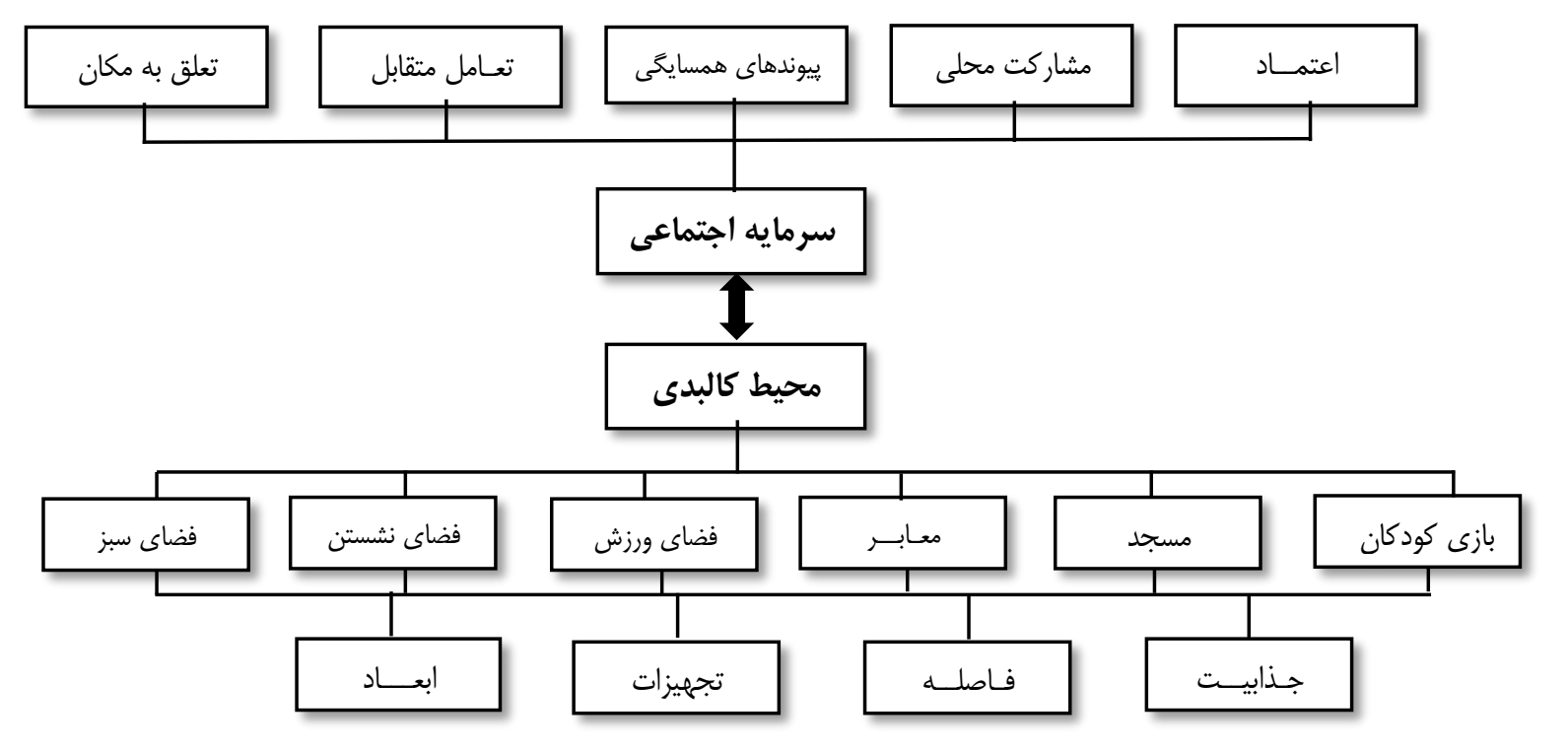

تصوير ا: متغيرها و مؤلفهاى يزوهش (مدل يزوهش)

Fig. 1: variables and indicators

90 در يكسى از نمونسههـا ( (n=0) انجـام شـــ و در نهايست يرسشنامه كه شامل باع برسش بود (ع آبرسش بــراى سـرمايه

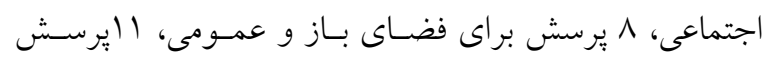

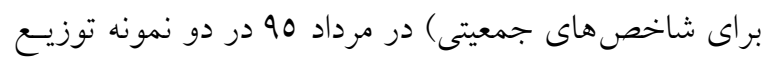

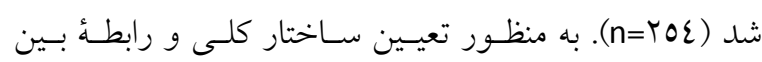
متغيرها از الكوى معادلات ساختارى و براى تحليل دادههـاى

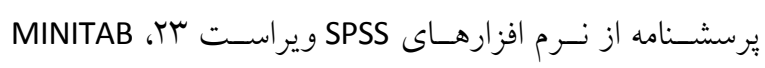

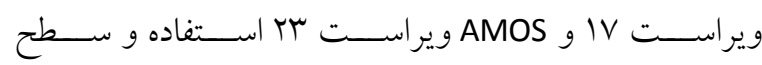
معنى دارى 0 • • در نظر كرفته شده است. r. مشاهدات، مكان محور بودند و در آنها جنسيت، ردهُ سنى (كودى، جوان، ميانسال، مسن)، نوع فعاليـت (صـحبت،

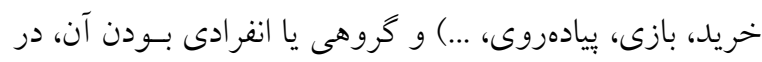
دو بازه زمـانى (صـبح و عصـر) و دو روز مختلـف در هفتـه (ميان هفته و مشنبه) ثبت مىشد كـه در نهايست در دو نمونسه

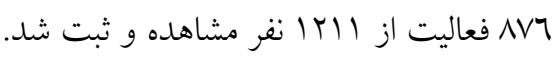
م. مدارك و اسناد. بررسى و شناخت اوليـهُ محـلات بـر اسـاس نقشـهـهـاى موجــود از محـلات (در فرمست dwg)، نقشههاى شهرى، و عكسهاى هوايى (Google Earth) آغـاز

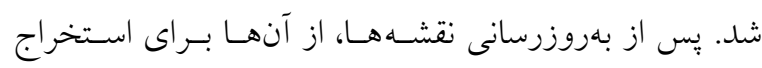
اطلاعات كالبدى دو نمونه نظيـر تـراكم، سـطح فضـاى بـاز، كاربرىها و ... استفاده شد.
فاصـله، r. ابعـاد، r. تجهيـزات، ع. زيبـايى و جــابيت بـراى

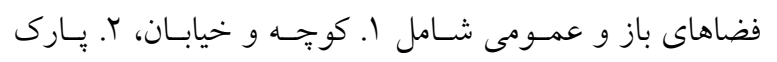
محلى، ז. فضاى نشستن، ع. فضاى بازى كودكـان، 0.

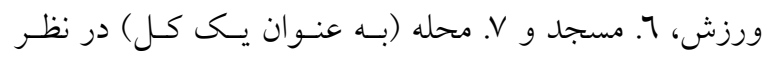

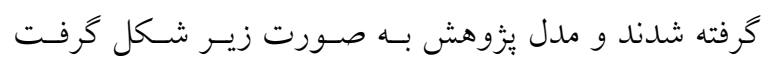

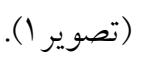

ب) گردآورى دادهها و روش تحقيست: يـزوهش بــراى

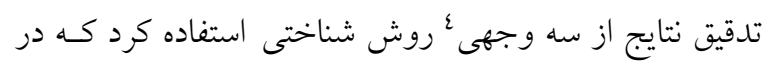

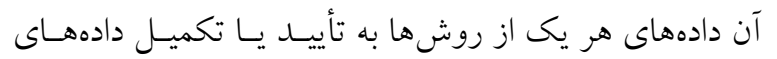

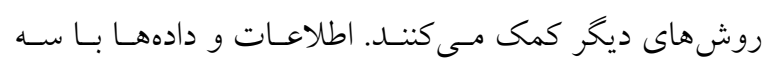
روش بيمايش، مشاهدات رفتارى، ساختار عينى خـردآورى و

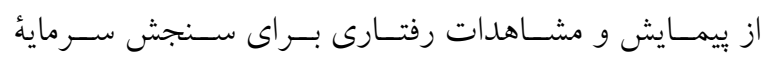
اجتماعى و بيمايش و ساختار عينى محله براى سنجش محيط كالبدى استفاده شده است: ا.بيمايش، كـه در آن محسيط كالبـدى همســايخى متغيـر مستقل و سطح سرمائُ اجتماعى ساكنان متغير وابسـته تحقيـق

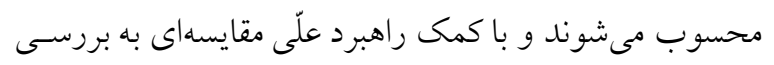

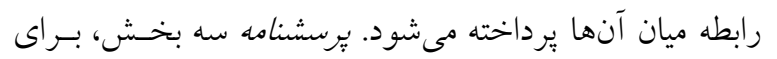

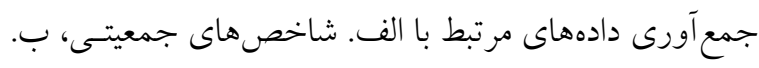
سرمايه اجتماعى، و ج. ادراك محيط كالبـدى توسـط سـاكنان دارد. براى اطمينان از پيايايى يرسشنامه، آزمـون اوليـهـ در بهـار 
بررسى رابطؤ سرمايه اجتماعى و محيط كالبدى محلات مسكونى با تأكيد بر فضاهاى باز و عمو مى

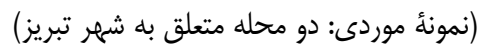

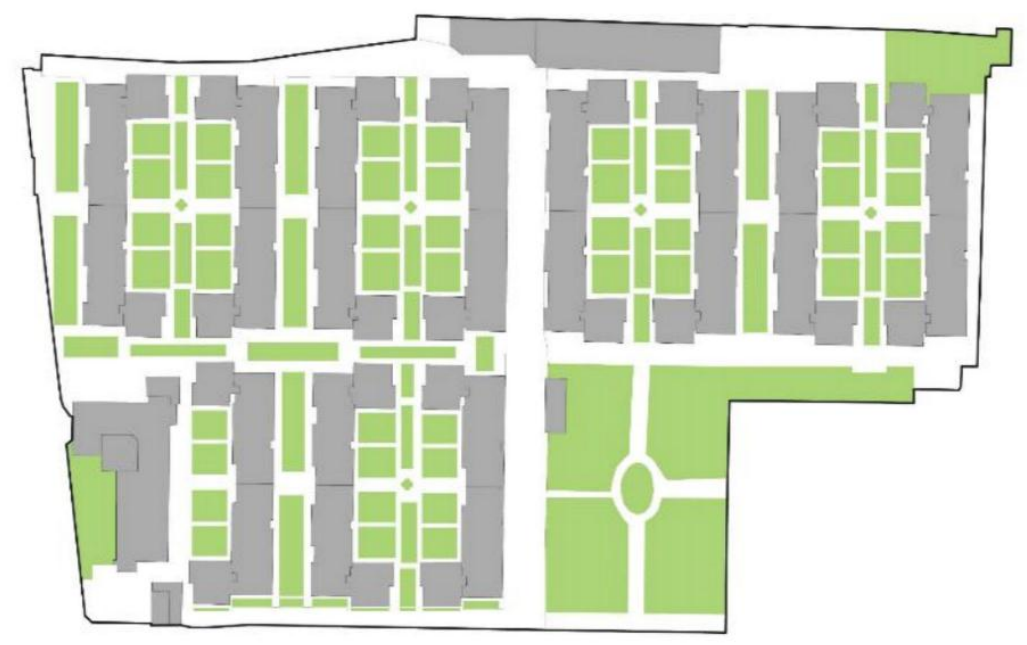

تصوير ז: مجتمع جمران (نمونه () (Sampl)

Fig. 2: Chamran Complex (Sample 1)

(تصوير r) در قالب بلوكهاى سه تا ينج طبقـه طراحسى شـده است، محصور است و ورودىى و خروجى كتــرل شـده دارد. اين مجموعه يك فضاى سبز عمـومى، زمسين ورزش، تعـداد

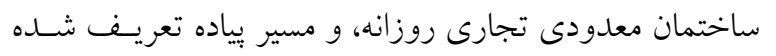

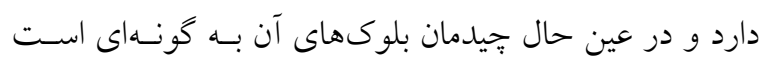
كه حياطهايى نيمه خصوصى بـين آنهـا ايجـاد شـده اسـت.

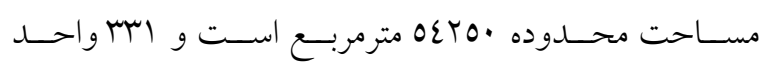

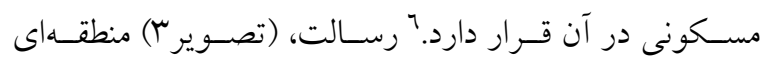
مسكونى است كه در آن آيارتمانهاى سه تا هشت طبقه در
Koohsari et al. ) نمونه Kـا: از آنجـا كـه تحقيقـات (2012; Wood 2006; Kang 2006 وضعيت اقتصادى اجتماعى نمونهها (با توجه به تأثير آنها بـر

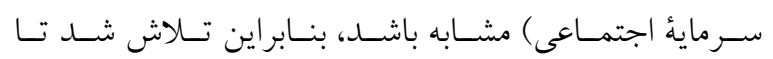

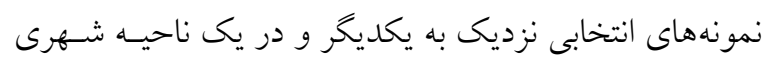
باشند و در همان حال محيط كالبدى آنها متفاوت باشـــ. بـر

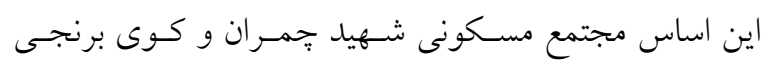

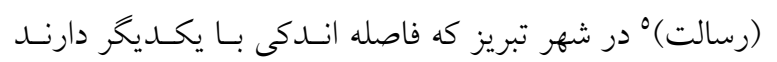

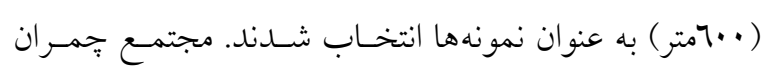

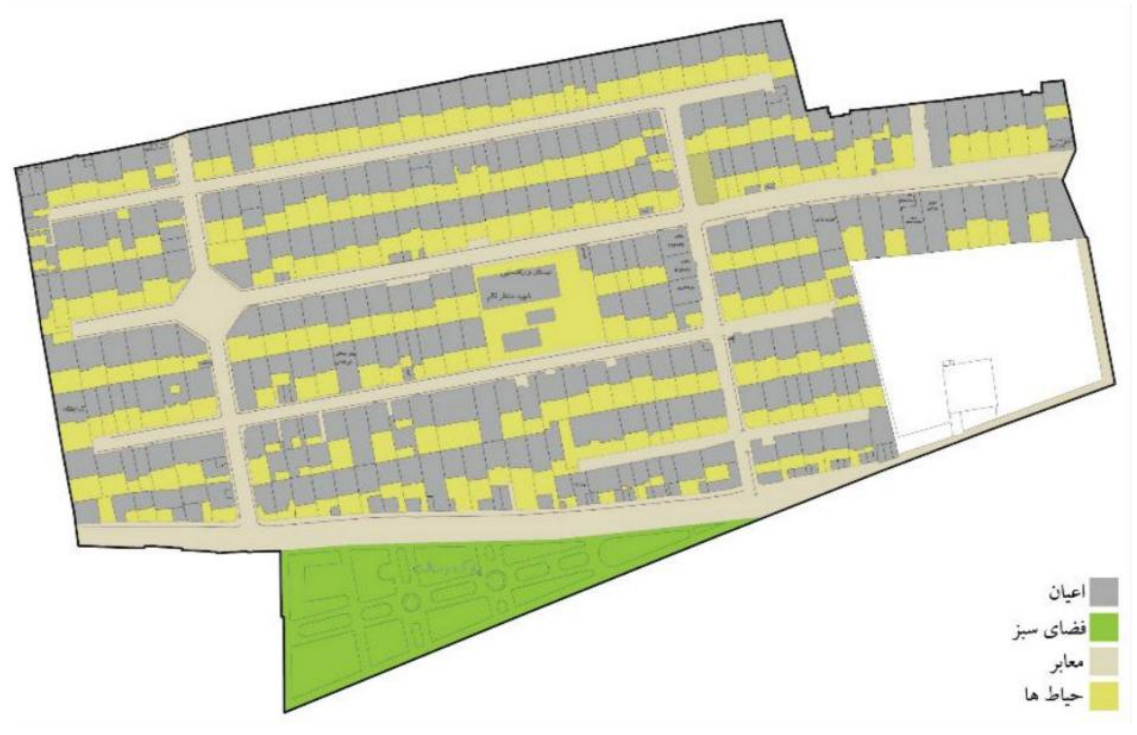

تصوير ب: محدوه رسالت (نمونه r)

Fig. 3: Resalat Restrict (Sample 2)

فرهنَّ معمارى و شهرسازى اسلامى - سال ينجمه، شماره دوم- پاييز و زمستان 99 | 
آنها بر آزمون در نظـر كرفتـه شـــ و مشـخص شـد كـه دو فاكتور جنسـيت و نـوع مالكيـت (اسـتيجارى يـا تملـك) بــر سرمائه اجتماعى تأثير معنى دار داشتهانـد (جــدول ع). بـس از اعمال دو فاكتور مذكور و تحليل مجلد دادهها، تفـاوتهـيى اندك در مؤلفه (بيوندهاى همسايخى)" و (مشاركت محلى)" و

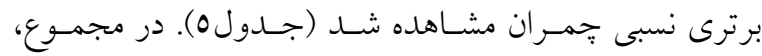

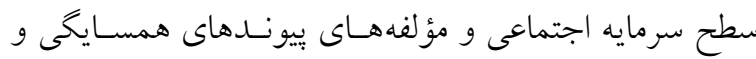
مشاركت محلى در جّمران اندكى بالاتر از رسالت است. ايسن

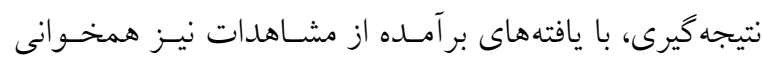
دارد. مقايسٔ فعاليت هاى گروهى و انفرادى در دو نمونه نشان بـان

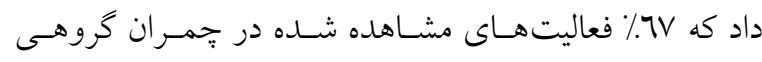
است، در حالى كه اين عدد در رسالت ^عـ٪ اسـت. همجنــين

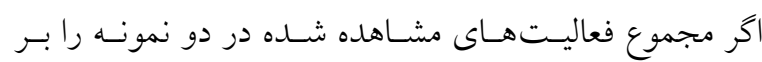
اساس تعداد واحد مسكونى معادل سازى كنيم جّمـــان امتيـاز بيشترى نسبت به رسالت بـه دسـت مسى آورد (جـدول6). بـهـ عبارتى ميزان حضور افراد در فضـاهاى بــاز و عمـومى و نيـز فعاليتهاى گروهى آنها در جِمران بيشـتر از رسـالت اسـت.

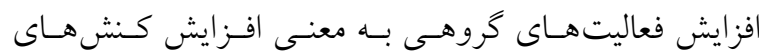
كروهى (اجتماعى)، تعـاملات، و بييونـدها اسـت و مسىتوانـد سبب بالا رفتن سطح سرمائُ اجتماعى شود. محيط كالبـدى: تحليـل ارزيـابى ادراكى سـاكنان از
كنار خانههاى يك يا دو طبقه وجود دارند. شبكهُ معابر آن

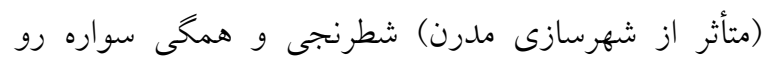
هستند. تجارىهاى روزانه، مسجد و مدرسه در جداره يكى آنى

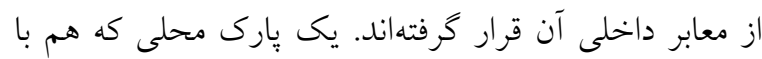
يك خيابان عبورى از محله جدا شده و هم با محلههاى مجاور مشترى است، در جنوب آن وجود دارد. محدودة مطالعاتى ·. . · · مترمربع مساحت دارد و داراى 910 و احد

$$
\text { مسكونى است. }
$$

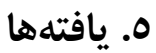

شاخص هاى جمعيتى: علاوه بر شاخص هاى جمعيتى كـه در

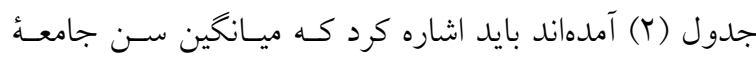

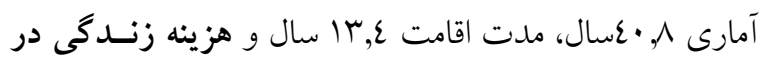
ماه rاميليون ريال بوده است.

سرمايه اجتماعى: دادههاى بيمايش نشان داد كـه سـطح

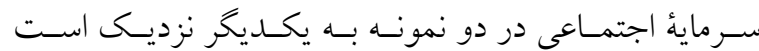
(جدول (1). در بين مؤلفههاى ينج گانهُ سرماية اجتماعى تنها در مؤلفه (مشاركت محلىى) تفـاوت معنسى دارى ديــه شـــ و در

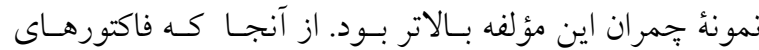
Field ) جمعيتى بر سطح سرمائُ اجتماعى مؤثر دانسته شدهاند 2006) با استفاده از آزمون تحليل واريانس يـك طرفـه، تـأثير

جدول r: شاخصهاى جمعيتى نمونهها

Table 2: Social Economic Factors of Samples

\begin{tabular}{|c|c|c|c|c|c|c|c|}
\hline \multicolumn{2}{|c|}{ جمع } & \multicolumn{2}{|c|}{ رسالت } & \multicolumn{2}{|c|}{ جمران } & \multirow{2}{*}{\multicolumn{2}{|c|}{ متغير }} \\
\hline درصد & فراوانى & درصد & فراوانى & درصد & فراوانى & & \\
\hline rq & $v^{e}$ & $r V / \&$ & er & $m /{ }^{c}$ & MT & مرد & \multirow{2}{*}{ جنسيت } \\
\hline n & $1 \Lambda$ & $V T / T^{\circ}$ & 11. & SN/9 & v. & زن & \\
\hline$r T / S$ & $\Delta V$ & $\mathrm{IV} / \mathrm{V}$ & TV & $r q / 4$ & $r$. & مجرد & \multirow{2}{*}{ تأهل } \\
\hline 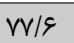 & 198 & $\Lambda T / r$ & ITA & $V \cdot / 9$ & $v r$ & متأهل & \\
\hline$\Delta F$ & Iet & $\Delta \Delta / r$ & $\wedge f$ & $\Delta \& / \Lambda$ & $\Delta \Lambda$ & دييلم يا كمتر & \multirow{2}{*}{ تحصيلات } \\
\hline pe & 111 & 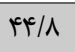 & 81 & $r \pi / T$ & pe & بالاى دييلم & \\
\hline$r \Delta / r$ & 94 & $r F / r$ & rv & $r \varepsilon / Q$ & $T V$ & شاغل & \multirow{2}{*}{ اشتغال } \\
\hline$v e / \Lambda$ & 19. & $V \Delta / V$ & 110 & $V \pi / \Delta$ & VQ & خانهدار، بازنشسته & \\
\hline$V N / F$ & 199 & $V V / s$ & 111 & $v 9 / 4$ & $\wedge$ & مالى & \multirow{2}{*}{ وضعيت مالكيت } \\
\hline TI/S & $\Delta \Delta$ & $r T / T^{c}$ & re & $r \cdot 18$ & rI & اجارواى & \\
\hline
\end{tabular}


بررسى رابطأ سرمايه اجتماعى و محيط كالبدى محلات مسكونى با تأكيد بر فضاهاى باز و عمو مى

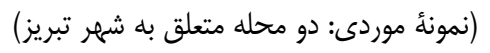

جدول س: توصيف ابعاد متغير سرمايه اجتماعى در ميان آزمودنىها

Table 3: Describing the dimensions of social capital among subjects

\begin{tabular}{|c|c|c|c|c|c|}
\hline انحر اف معيار & 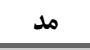 & 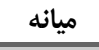 & ميانَين & محله & زيرمقياس \\
\hline r/or & $10 / \cdots$ & $1 \% / \cdot$ & $11 / 19$ & جمران & \multirow{2}{*}{ تعامل متقابل } \\
\hline$r / 0 \Lambda$ & $11 / \cdots$ & $11 \% /$. & $15 / 19$ & رسالت & \\
\hline $0 / 1 V$ & rql.. & rql... & $r \Delta / \cdot 9$ & جمران & \multirow{2}{*}{ ييوندهاى همسايخى } \\
\hline $0 / 19$ & rN/.. & $r \Delta / \cdots$ & TY/VT & رسالت & \\
\hline$\varepsilon / 7 r$ & $r F / \ldots$ & rm/... & tr/TA & جمران & \multirow{2}{*}{ اعتماد } \\
\hline$\varepsilon / 09$ & $r M / .$. & r & rthe & رسالت & \\
\hline$\varepsilon / V_{0}$ & rm/.. & $r y / \ldots$ & $r F / T r$ & جمران & \multirow{2}{*}{ مشاركت در محله } \\
\hline$\varepsilon / \varepsilon$ & $r \Delta / \cdots$ & $r Y / .$. & rr/A9 & رسالت & \\
\hline$\varepsilon /+1$ & $1 \% / \cdots$ & $11 \%$ & $1 \% / M$ & جمران & \multirow{2}{*}{ تعلق به مجموعه } \\
\hline$r / q \varepsilon$ & $191 \ldots$ & $1 \% / .$. & $1 \% / \cdot r$ & رسالت & \\
\hline $10 / 9$ & $9 \diamond / \cdots$ & $1 \ldots 1 \ldots$ & $9 / 1 / 1$ & جمران & \multirow{2}{*}{ سرمايه اجتماعى } \\
\hline$|\varepsilon / \Lambda|$ & $91 / \ldots$ & $9 / / 0$. & $q \vee / 4 q$ & رسالت & \\
\hline
\end{tabular}

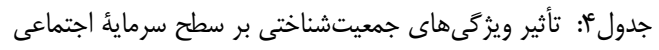

Table 4: Impact of demographic characteristics on level of social capital

\begin{tabular}{|c|c|c|c|c|c|}
\hline 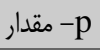 & F آماره F & ميانخين & محله & رده & ويزگى جمعيت شناختى \\
\hline \multirow{2}{*}{$\cdot|\cdot 4|$} & \multirow{2}{*}{ ( } & $1 \cdot r / V I$ & 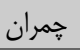 & \multirow{2}{*}{ 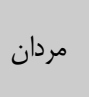 } & \multirow{4}{*}{ جنسيت } \\
\hline & & $1.1 / 99$ & 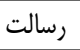 & & \\
\hline \multirow{2}{*}{$.1 . \operatorname{tet}$} & \multirow{2}{*}{ T/ETA } & $9 \vee / \Delta$. & جمران & \multirow{2}{*}{ 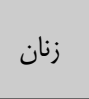 } & \\
\hline & & $9 \Delta / r /$ & 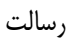 & & \\
\hline \multirow{2}{*}{.1 .198} & \multirow{2}{*}{ r/Ir } & ११/. r & 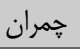 & \multirow{2}{*}{ 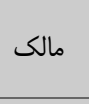 } & \multirow{4}{*}{ وضعيت مالكيت واحد مسكونى } \\
\hline & & 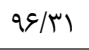 & سالت & & \\
\hline \multirow{2}{*}{$.1 .1 \mathrm{~V}$} & \multirow{2}{*}{ r/Dgr } & $91 / 4 \varepsilon$ & جمران & \multirow{2}{*}{ اجارهاى } & \\
\hline & & $q \mu / v \varepsilon$ & رسالت & & \\
\hline
\end{tabular}

جدول 0: تأثير ويزگى هاى جمعيت شناختى بر مؤلفهاى سرمايةٔ اجتماعى

Table 5: Impact of demographic characteristics on level of social capital's Components

\begin{tabular}{|c|c|c|c|c|c|c|}
\hline p - مقدار & آماره F F & ميانگين & محله & رos & ويزَّى جمعيت شناختى & مولفه \\
\hline \multirow{2}{*}{$\cdot 1 \cdot r q$} & \multirow{2}{*}{ r/va. } & re/ Rit & جمران & \multirow{2}{*}{ مردان } & \multirow{4}{*}{ جنسيت } & \multirow{8}{*}{ بيوندهاى همسايكى } \\
\hline & & $r \Delta / \varepsilon$. & رسالت & & & \\
\hline \multirow{2}{*}{./H人 } & \multirow{2}{*}{ I/TMF } & TY/TY & جمران & \multirow{2}{*}{ 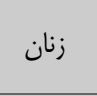 } & & \\
\hline & & $r F /+1$ & رسالت & & & \\
\hline \multirow{2}{*}{$\cdot 1+r$} & \multirow{2}{*}{ r/qQF } & س & جمران & \multirow{2}{*}{ 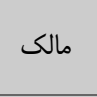 } & \multirow{4}{*}{ وضعيت مالكيت واحد مسكونى } & \\
\hline & & rm/qu & رسالت & & & \\
\hline \multirow{2}{*}{$\cdot 1 \cdot+4 \wedge$} & \multirow{2}{*}{$r / 1 \ldots$} & $r F / \Delta F$ & جمران & \multirow{2}{*}{ اجارهاى } & & \\
\hline & & rM/AT & رسالت & & & \\
\hline \multirow{2}{*}{$\cdot 1 \cdot r \cdot$} & \multirow{2}{*}{$\Delta / \hat{T} \Delta V$} & $r t / 4$ & جمران & \multirow{2}{*}{ مردان } & \multirow{4}{*}{ جنسيت } & \multirow{8}{*}{ مشاركت در محله } \\
\hline & & سM/M & رسالت & & & \\
\hline \multirow{2}{*}{$.1+.9$} & \multirow{2}{*}{ 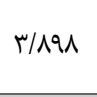 } & rr/qr & جمران & \multirow{2}{*}{ 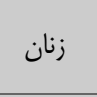 } & & \\
\hline & & tr/TM & رسالت & & & \\
\hline \multirow{2}{*}{$\cdot 1+\Delta$} & \multirow{2}{*}{$V / \Lambda \cdot r$} & rg/r & جمران & \multirow{2}{*}{ 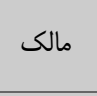 } & \multirow{4}{*}{ وضعيت مالكيت واحد مسكونى } & \\
\hline & & سוזr & رسالت & & & \\
\hline \multirow{2}{*}{$\cdot 1 \cdot 1$} & \multirow{2}{*}{ G/gme } & re/Tr & جمران & \multirow{2}{*}{ اجارهاى } & & \\
\hline & & $r T / V T^{c}$ & رسالت & & & \\
\hline
\end{tabular}


جدول \&: معادل سازى امتيازات مشاهدات رفتارى در نمونهها

Table 6: Equalization of scores of behavioral observations in samples

\begin{tabular}{|c|c|c|c|c|c|c|c|c|}
\hline \multicolumn{4}{|c|}{ جمران } & \multicolumn{4}{|c|}{ رسالت } & \\
\hline \multicolumn{2}{|c|}{ امتياز } & \multicolumn{2}{|c|}{ نفر } & \multicolumn{2}{|c|}{ امتياز } & \multicolumn{2}{|c|}{ نفر } & \\
\hline معابر & يار ك & معابر & 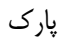 & معابر & يارى & معابر & يارى & \\
\hline eV & TF, & 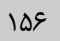 & 1) & ऍ^,ه & אוז" & ז' & זسו & جمع \\
\hline \multicolumn{2}{|c|}{ VI, r } & & & \multicolumn{2}{|c|}{01,1} & & & جمع (امتياز كل) \\
\hline
\end{tabular}

مزايا، Vo٪ معابر جّمران به يِياده اختصـاص دارد، از منظـرى

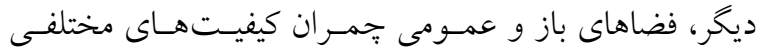
دارند و مىتوان عرصههاى نيمهعمومى (حياط بين بلـوكهـا) و عرصه عمومى (يارك محله) را در مجموعه نام برد. تفكيك فضايى و عملكردى، در كنار سطح وسيع فضـاى بــاز، تـراكم كم، و تسهيل حركت يِياده در جمران همخسى شـاخصهـيى هستند كه ارزيابى مثبتى از مجموعه به دست دادهانـا و آن را

$$
\text { براى حضور و كنش اجتماعى ساكنان مناسب مى كنند. }
$$

در مجموع، تفاوت در شاخص هاى عينى دو نمونه قابـل توجه بود و انتظار مىرفت ارزيابى اداركى سـاكنان از محسيط كالبدى محلهُ خود نيز تفاوتى قابل توجه و همسطح با تفاوت در شاخص هاى عينى داشته باشد اما اين اختلاف انـدى بـود. يافتن دلايل اين امر مىتواند موضوع بزوهشهاى ديخر باشد،

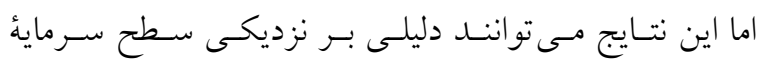
اجتماعى در دو نمونه نيز باشند.
فضاهاى باز و عمومى و اطلاعـات توصسيفى محسيط كالبـدى نشان مىدهند كه رضايت افراد از فضاهاى بـاز و عمـومى در ميان ساكنان جّمران اندكى بيشتر از رسالت اسـت (جــدول).

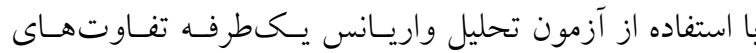
معنى دارى در برخى مؤلفههاى فضاهاى باز و عمومى مشاهده شد. رضايت ساكنان جِمران از (ابعـاد و انــازهه) و (جــابيت)" فضاهاى بــاز و عمـومى بيشـتر از سـاكنان رسـالت بـود و در مؤلفههاى ديخر تفاوت معنى دارى ديده نشد. اما بررسى شاخصىهاى عينى دو نمونه، نكات جديسـى را بـه يُزوهش عرضه مى كنند (جاوله). نمونهُ رسالت معابر بياده و فضاى سبز كمتر دارد و در همان حال تراكم، سـطح سـوارهو سطح اشغال در آن بيشتر اسـت. سـطح فضـاى سـبز جمــران جهار برابـر بيشـتر از رسـالت اسـت، و همــهُ ايسن نسـبتهـا

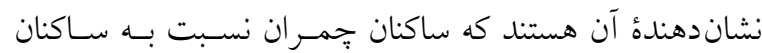
رسالت فضاى باز وسيع ترى را در اختيار دارند. در كنـار ايـن

جدول V: توصيف ابعاد متغير فضاهاى عمومى در ميان آزمودنىها

Table 7: Describing the dimensions of public open spaces among subjects

\begin{tabular}{|c|c|c|c|c|c|}
\hline انحراف معيار & مد & ميانه & ميانكَين & محله & زيرمقياس \\
\hline r/^q & $\mid r / \cdot$. & $\mid r / \cdot$. & $11 / 9 V$ & جمران & \multirow[t]{2}{*}{ ابعاد و اندازه } \\
\hline$T / V T$ & $9 / .$. & $11 / \cdot$. & $1 . / 9 \pi$ & رسالت & \\
\hline T/צT & $1 . \%$ & 1.1. & 1.18 & جمران & \multirow[t]{2}{*}{ تجهيزات } \\
\hline$r / \& V$ & १/.. & $1 \cdot / 0$. & $1 . / V T$ & رسالت & \\
\hline$r / \cdot G$ & 1.1. & 1.1. & $9 / \Delta \Delta$ & جمران & \multirow[t]{2}{*}{ فاصله } \\
\hline$r / \cdot \Lambda$ & 1.1. & $1.1 . \cdot$ & $9 / 94$ & رسالت & \\
\hline$p /$ qq & $r \cdot \%$ & $19 / .$. & $I N / T V$ & جمران & \multirow[t]{2}{*}{ جذابيت } \\
\hline$r / r \Lambda$ & $\mid \mathrm{V} / \cdot$. & $\mid V / \cdot$. & $\mid s / \Delta V$ & رسالت & \\
\hline $18 / \% q$ & $\wedge \mathrm{V} / \cdot$. & $\Lambda V / \Delta$. & $\Lambda \varepsilon / \lambda$. & جمران & فضاهاى \\
\hline $\mid \omega / \cdot V$ & $\Lambda \kappa /$. & $\Lambda F / .$. & $\Lambda F / \& \Lambda$ & رسالت & عمومى \\
\hline
\end{tabular}


بررسى رابطة سرمايه اجتماعى و محيط كالبدى محلات مسكونى با تأكيد بر فضاهاى باز و عمو مى

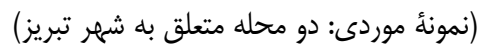

جدولم: شاخصهاى عينى نمونهها

Table 8: subjective indicators

\begin{tabular}{|c|c|c|}
\hline 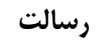 & 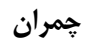 & \\
\hline D.rt. & DFTA. & مساحت كل (متر مربع) \\
\hline $91 \mathrm{~A}$ & 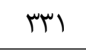 & تعداد واحدهاى مسكونى \\
\hline$\% 11, \infty$ & $\cdot$ & خانه (الكَوى سكونت) \\
\hline$\%$ \%, & $\%$ & آيار تمان (الََوى سكونت) \\
\hline 90 & 91 & تراكم (هكتار /واحد) \\
\hline$\% \mathrm{~V}$. & Ir. & تراكم مسكونى \\
\hline$\% \wedge, \Delta$ & $\% \cdot, 1$ & تجارى، آموزشى، مذهبى، ... \\
\hline$\% \wedge, \Delta$ & $\%$ & فضاى سبز (يارك محلى) \\
\hline$\% / 91, \Delta$ & $\%$ & مسكونى (عرصه) \\
\hline$\%(r), \Delta$ & $\%$ & معابر \\
\hline$\%$ & $\% 90$ & فضاهاى باز عمومى \\
\hline$\% \Delta F, \Delta$ & $\% 90$ & فضاهاى باز \\
\hline$\% \vee \Delta, r$ & $\%$ ra & نسبت سطح سواره (سطح معابر /سطح سواره) \\
\hline$\% r F, V$ & $\% \vee v$ & نسبت سطح يياده (سطح معابر /سطح يياده) \\
\hline
\end{tabular}

از سوى ديخر، استفاده از تحليل گروههـاى جنــــ متغيــه

نشان داد كه رابطةٌ فضاهاى عمومى با سرمايةٔ اجتمـاعى در دو

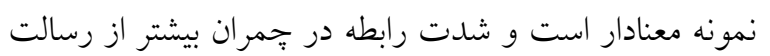

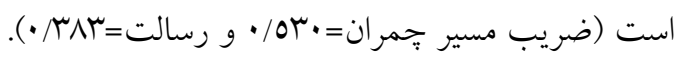
مؤلفهاى كالبدى و سرمائُ اجتماعى: در سطح بعـىى

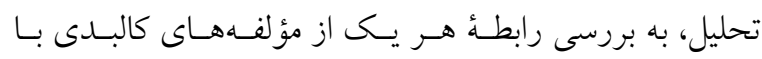

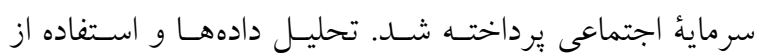

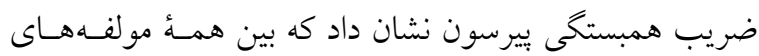
فضاهاى باز و عمومى با سرمايه اجتماعى رابطـه معنسى دار از نوع افزايشى وجود دارد، و در بين ايـن مؤلفـهـــا قـوىتـرين رابطه، بين (جذابيت) و سرمائُ اجتماعى (ع|V/V) وجود دارد (جدول • (). بررسى شدت رابطة هر يك از مؤلفهها با سرمائٔ
رابطهُ سرمايه اجتماعى و محسيط: از تحليـل دادههـا بـاــا

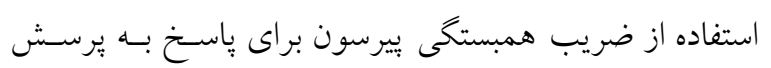
يزوهش استفاده شد و فرضيات يزوهش تأييــ شــند. نتـايج نشان دادند كه ميان فضاهاى باز و عمومى محلات و سـرمائ

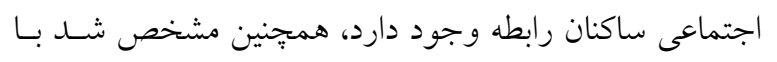
افـزايش حضـور افــراد در فضـاهاى بــاز و عمـومى، ســمايه

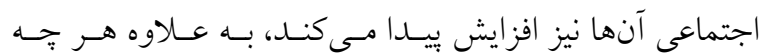
رضايت افراد از اين فضاها بيشتر باشد ميزان حضسور آنهـا و ليز در نتيجه، سرمايه اجتماعى افزايش مسىيابــ (جــدول9). ايسن نتيجه همسو با نتايج رفتارى است (جدول7)، در نمونهاى كـه حضـور افـراد در آن كمتـر اسـت (رسـالت) سـطح سـرمائ اجتماعى ساكنان آن نيز يايينتر است.

جدولج: آزمون فرضيات، بررسى رابطه بين ميزان حضور افراد در فضاهاى باز و عمومى، رضايت و سرمايه اجتماعى

Table 9: Investigating the relationship between the presence of individuals in open and public spaces, satisfaction and social capital

\begin{tabular}{|c|c|c|c|c|}
\hline نوع رابطه & فراوانى & - p - مقدار & ضر يب همبستكى ييرسون & متغير \\
\hline مستقيم & TAF & $.1 . .1$ & ./frq & ميزان حضور افراد در فضاهاى باز و عمومى و \\
\hline مستقيم & TQF & $\cdot 1 \cdots 1$ & $\cdot /$ fVq & ميزان رضايت افراد از فضاهاى باز و عمومى و \\
\hline مستقيم & TAF & $.1 . .1$ &.$/ 19 \Lambda$ & ميزان حضور افراد در فضاهاى باز و عمومى و \\
\hline
\end{tabular}


جدول • (: بررسى رابطه بين مؤلفههاى فضاهاى عمومى در برابر سرمائُ اجتماعى

Table 10: Investigating the relationship between public and open spaces indicators versus social capital

\begin{tabular}{|c|c|c|c|c|c|}
\hline جذابيت & فاصله & تجهيزات & ابعاد و اندازه & سرمايه اجتماعى & متغير \\
\hline & & & & 1 & سرمايه اجتماعى \\
\hline & & & 1 & 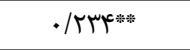 & ابعاد و اندازه \\
\hline & & 1 & - $/ V E T^{* *:=}$ & $\cdot / T V Q^{* *:}$ & تجهيزات \\
\hline & 1 & $\cdot \mid \Delta \Delta \Lambda^{* * *}$ & $\cdot 19 \cdot 1^{* * *}$ & . $/$ KYq** & فاصله \\
\hline 1 & $\cdot 19 \cdot V^{* *}$ & . & $\cdot / \Delta \Lambda^{* * *}$ & $\cdot / f^{4} \cdot V^{* * *}$ & جذابيت \\
\hline
\end{tabular}

(Kaźmierczak 2013)

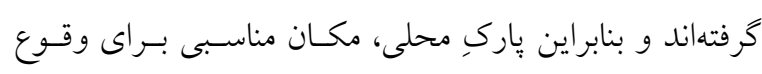

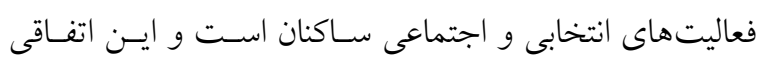

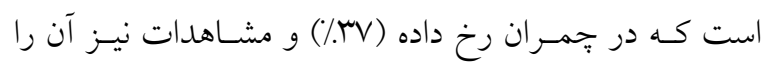

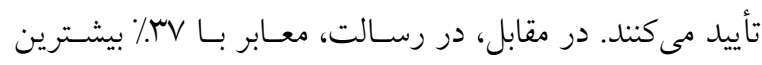
مكان براى ملاقات ها اعلام شده است. مشـاهدات نيـز نشـان

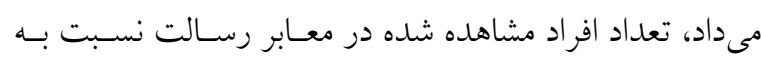

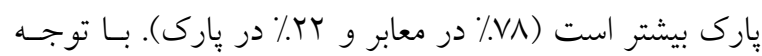
به آنكه معابر رسـالت اغلـب سـوارهرو هسـتند، بنـابر اين اولاً تعاملات در مكانى نامطلوب رخ مىدهند، ثانياً كنشها از نوع فعاليت هاى انتخابى و نه اجتماعى هستند كـه در نهايـت مسى توانند دليلى براى كـاهش سـرمايه اجتمـاعى باشـند. يكسى از نكات قابل توجه در رسالت، وقوع تعاملات در مسجد محلـه است كه بيان كننده اهميت نقش مسجد محله به عنوان مكانى براى تعاملات ساكنان است.

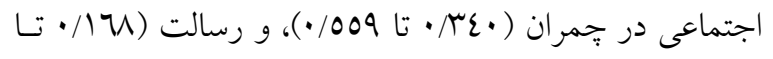
רسץ/•) نشان مى دهد كه رسالت در رتبهُ بإيين ترى قـرار دارد و به عبارتى محيط كالبدى رسالت در همهُ مؤلفـههـا كمتـــين رابطه را با سرمايه اجتماعى برقـرار كـرده اسـت. ايسن نتيجـه،

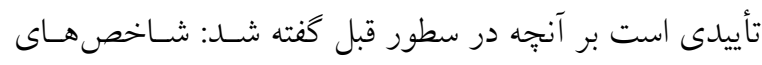
عينى رسالت و سطح سرمايه اجتماعى ساكنان آن يـايين تـر و كمترين رابطه بين محسيط و سـرمائ اجتمـاعى در آن برقـرار

مكانها و سرمائٔ اجتماعى: تحليل دادههـا و اسـتفاده از

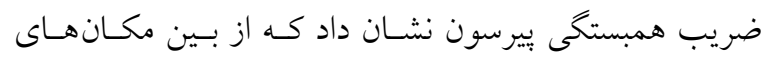
مختلف (تصوير () قوىترين رابطسه بـا سـرماية اجتمـاعى بـهـ

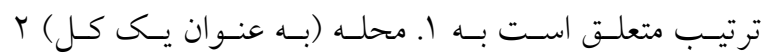
فضاهاى سبز و مّ. معابر (جدول (1). اهميت بارى و فضـاى. سبز و تأثير آن بر رضايت ساكنان از محلـه (Kaplan 1983) و نيـز بــه عنــوان مكـانى مهـــم بــراى شـكل گيــرى تعـاملات

جدول | (ا: بررسى رابطه بين انواع فضاهاى عمومى در برابر سرمايه اجتماعى

Table 11: Investigating the relationship between public and open spaces types versus social capital

\begin{tabular}{|c|c|c|c|c|c|}
\hline 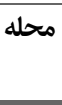 & فضاهاى باز و & فضاى بازى & كوجها، مسيرهاى يياده & سرمايه اجتماعى & متغير \\
\hline & & & & 1 & سر مايه اجتماعى \\
\hline & & & 1 & • & كوجهها، مسيرهاى بياده و دسترسى \\
\hline & & 1 & . /FTV **: & ./ ケฯ & فضاى بازى كودكان \\
\hline & 1 &.$|94|$ 粦 & •/OVG "*: & . & فضاهاى باز و عمومى محله \\
\hline 1 & $\cdot|\Delta|^{*}$ & . &.$/ 01 V^{* * *}$ & " & محله \\
\hline
\end{tabular}


بررسى رابطأ سرمايه اجتماعى و محيط كالبدى محلات مسكونى با تأكيد بر فضاهاى باز و عمو مى

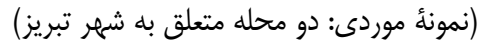

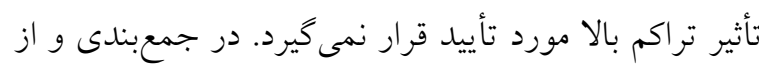

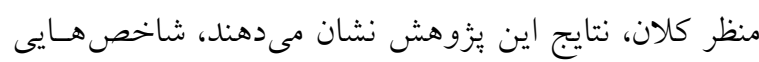

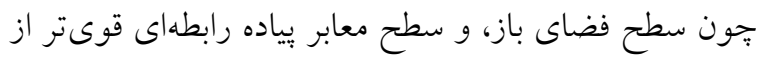
تر اكم با سرمايه اجتماعى دارند. اين يزوهش همجنين بيان مى كند كه ميان حضور افراد

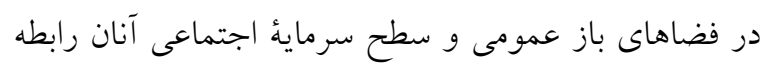
وجود دارد و در ميان مؤلفههاى اين فضاها جِنانجه جذابيت

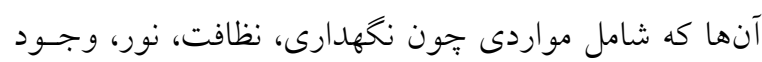

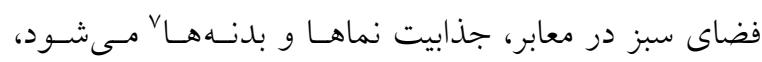

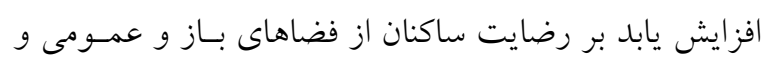

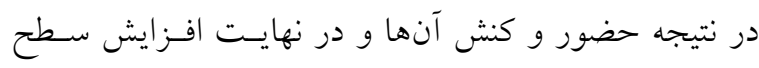

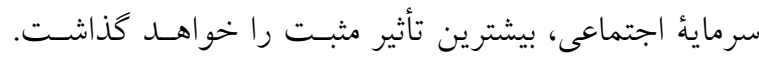

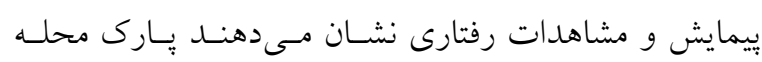

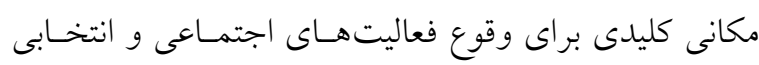

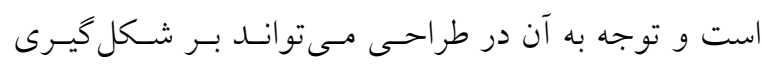

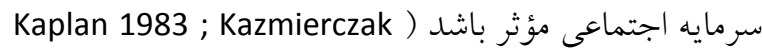

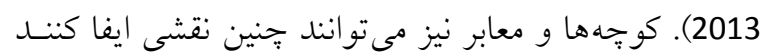

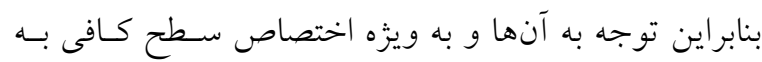

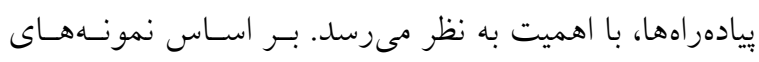

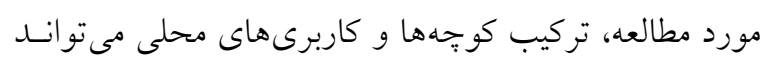

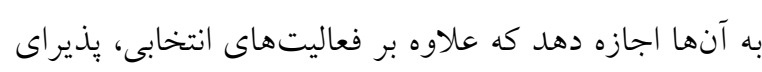

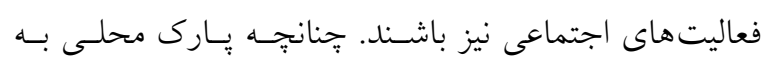
لحاظ كيفى و كمى، رضايت ساكنان را تأمين نكند، تعاملات

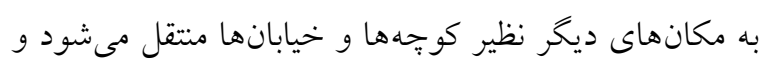

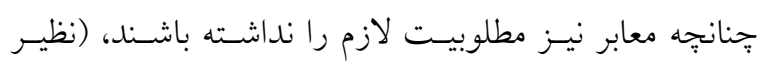

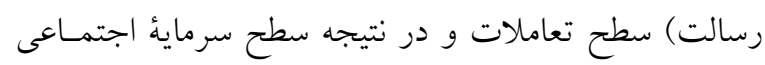

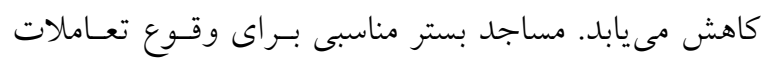

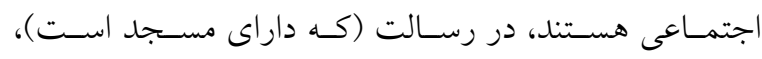

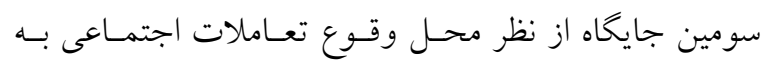
مسجد اختصاص دارد كه نشان دهندة نقش مؤثر يكى مركـز مذهبى بر تعاملات و سرمايه اجتماعى ساكنان است.

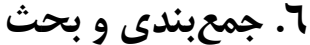

بررسى دادههـاى برآمـــه از ييمـايش و مشـاهدات نشـان

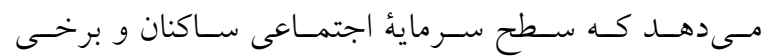

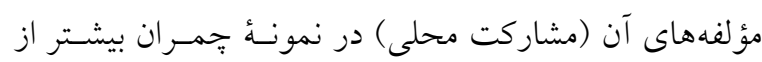

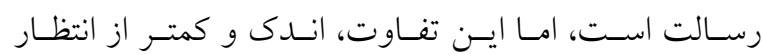

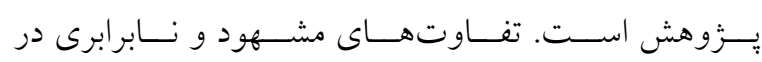
شاخص هاى عينى دو نمونه، نظير سطح معابر، فضاى سـبز،

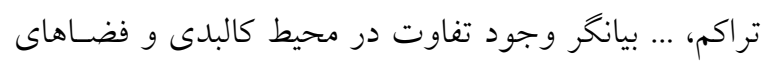

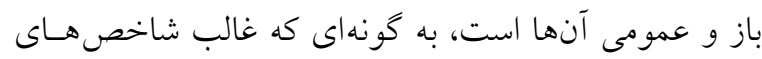

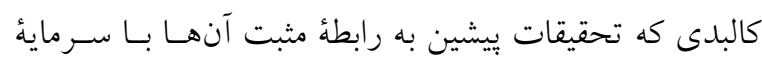

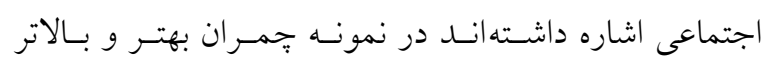

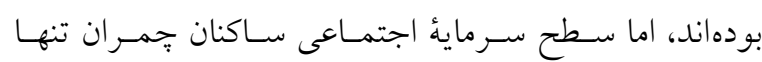

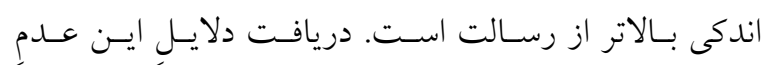

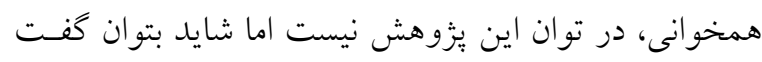

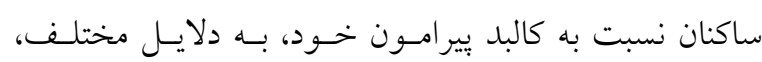

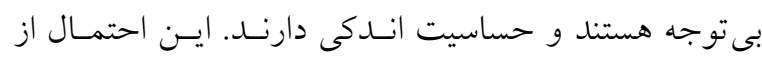

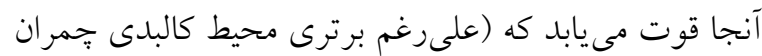

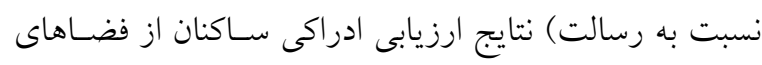
باز و عمومى در دو نمونه، نيز تفاوتهاى فاحشى را نشـان

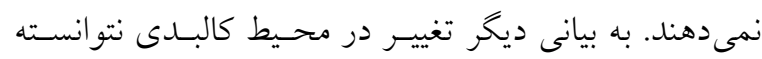
تغييرى معادل و همسطح در الكوهاى رفتارى كاربران و نيـز

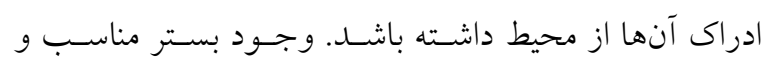

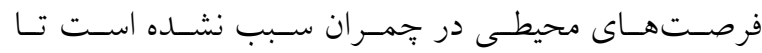

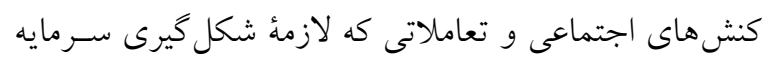

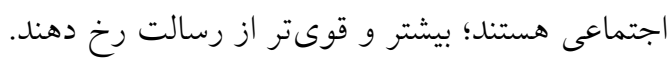

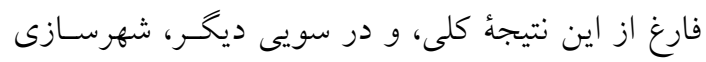

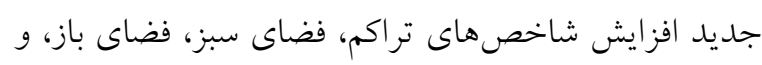

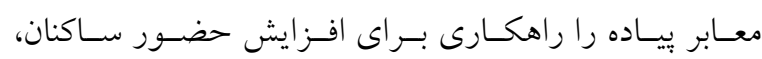
تعاملات اجتماعى، حس اجتماعى و ... دانسته اسـت. تـأثير

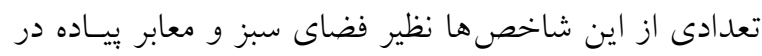

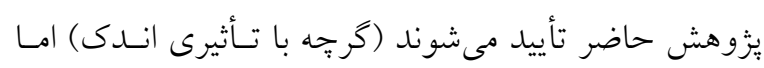




\section{نتيجه كيرى}

تفاوت داشت، اما سطح سرمايه اجتمـاعى سـاكنان و ارزيـابى

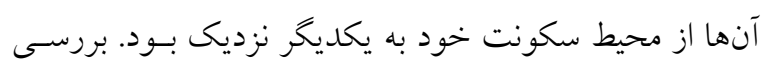

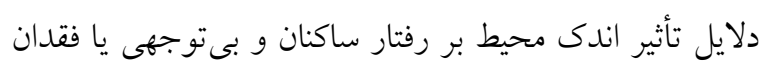

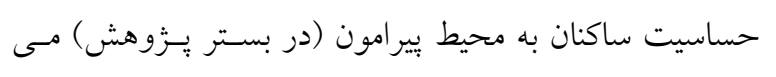

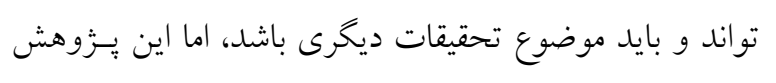

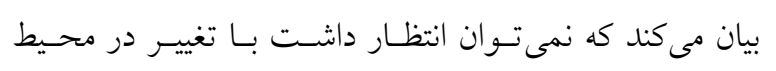
كالبدى، تغييرى متوازن و متعادل در الكوهاى رفتتارى سـاكنان ايجاد شود. وراى اين نتيجه كلى و قابل توجه، تحليل ها نشان

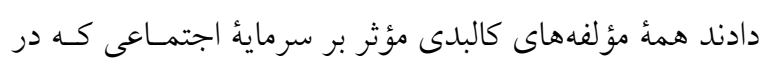

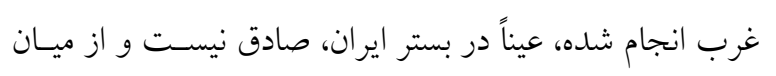
شاخص هاى كالبدى، شاخص سطح فضاى باز، و سطح معابر

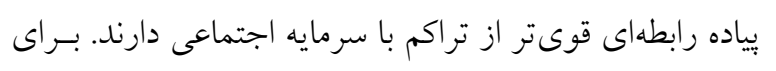

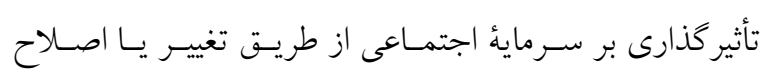

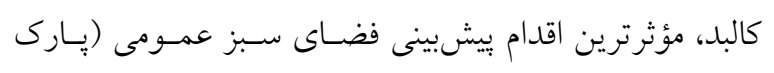

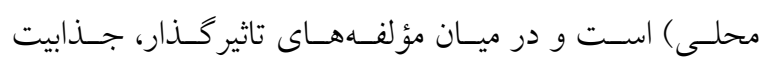

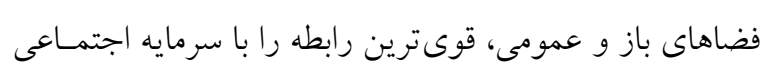
سـاكنان دارد. يزّوهش، در مجموع بيـان مسى كنـــ شـــت رابطــة ميـان

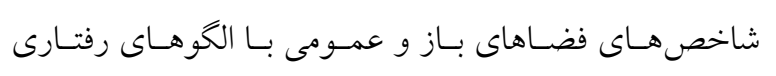

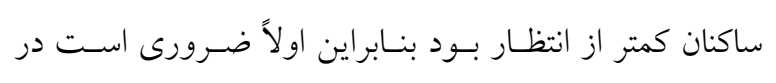

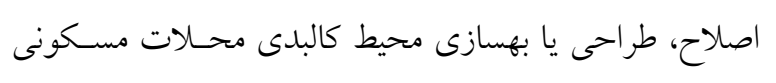

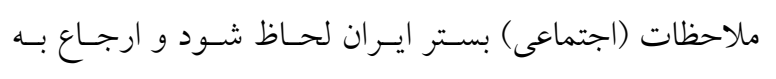

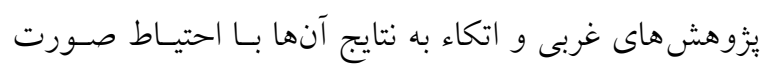

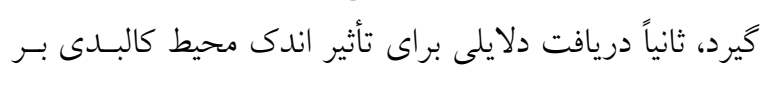

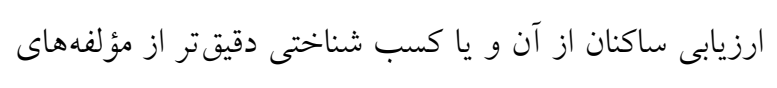

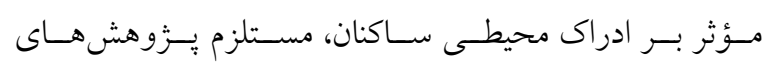

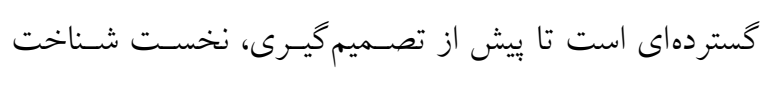

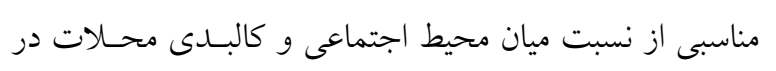
جامعه امروز ايران بهدست آيد.
سرمايه اجتماعى كه به منابع موجود در روابط افراد و كروههـا

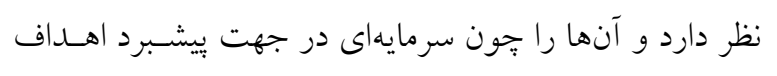

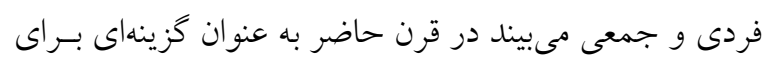

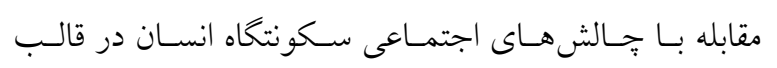
محلات و همسايكى ها مطرح شده است. استفاده از مفـاهيمى اجنى جون سرمايه اجتماعى كه در علوم و حوزههاى ديخــ مطرح

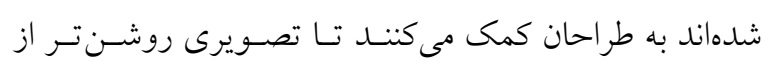

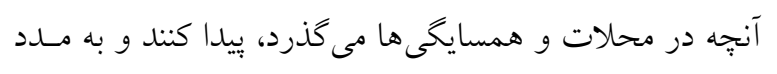

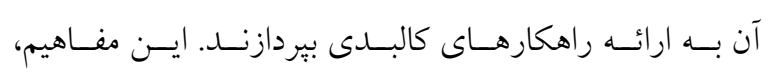

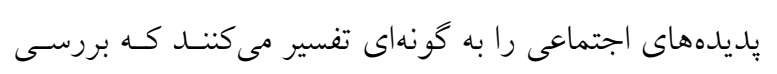

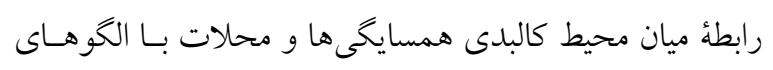

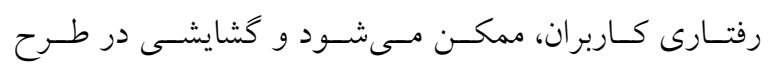

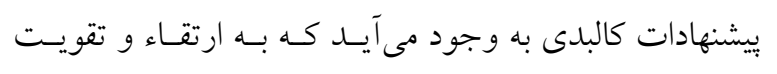

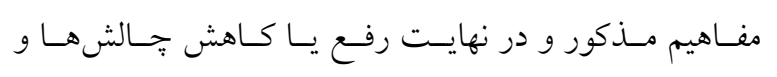

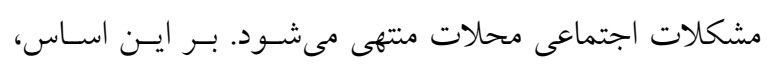

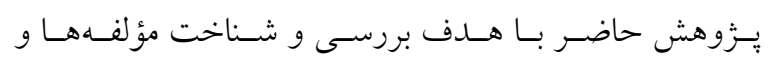
شاخص هاى كالبدى مؤثر بر سطح سرمايه اجتمـاعى سـاكنان در همسايكى ها، به مطالعه بر دو نمونه در شهر تبريز، متمركـز

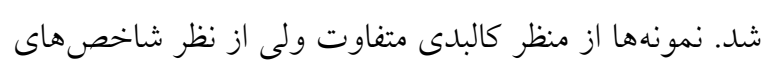

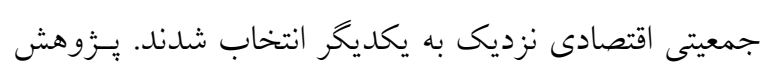

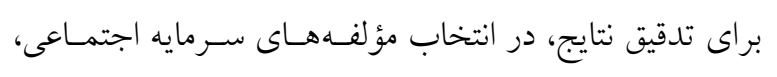

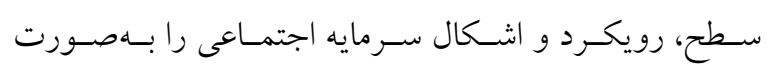
مشخص و شفاف تعيين كرد و در بررسى متغيرهـا (سـرمايه

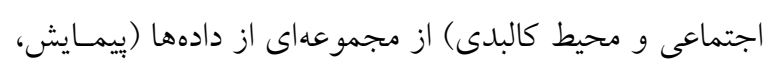

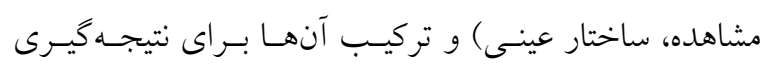
استفاده كرد. بررسى و تحليل دادها نشان داد، شاخصهـاى كالبـدى كرد

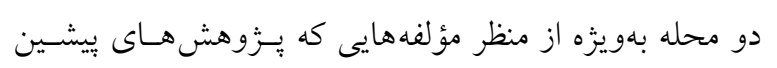

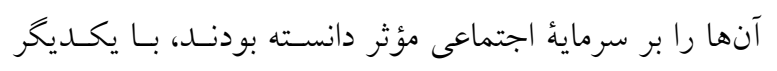




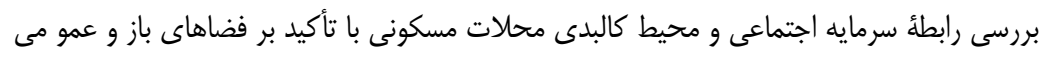

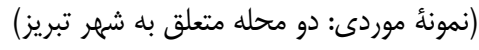

يحىنوشتها

Sense of Community . .

r. ا. ذكر همه منابع به دليل محدوديت مقاله از نظر حجم و صفحات مقدور نبود، جهت اطـلاع از جملـه نـك: Wood, Corti and Bulsara)

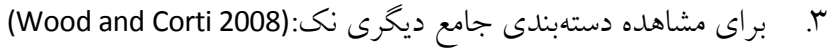

Triangulation $\varepsilon$

0. اين نام بيشتر در ميان ساكنان قديمى رواج داشته است و ساكنان جديد عموماً محله را به نام خيابان رسالت مىشناسند.

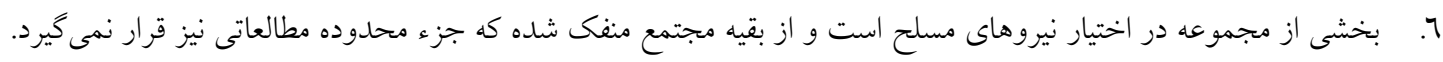

V. مؤلفه جذابيت ابنيه و نماها، معرف برداشت ذهنى افراد است و تبديل آن به مولفههاى معمارى مى تواند موضوع يزوهشى ديخر باشد.

$$
\begin{aligned}
& \text { فهرست منابع } \\
& \text { بحرينى، سيد حسين. }
\end{aligned}
$$

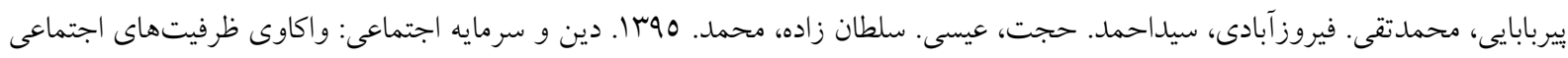

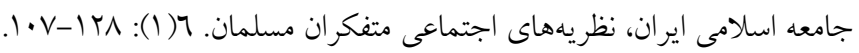

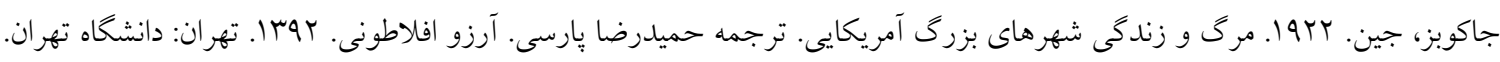

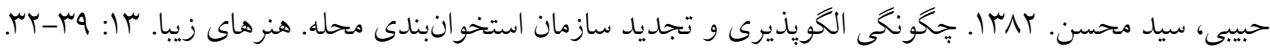

$$
\begin{aligned}
& \text { فوكوياما، فرانسيس. 1999. ويايان نظم (بررسى سرمايه اجتماعى و حفظ آن). ترجمه: غلامعباس توسلى. }
\end{aligned}
$$

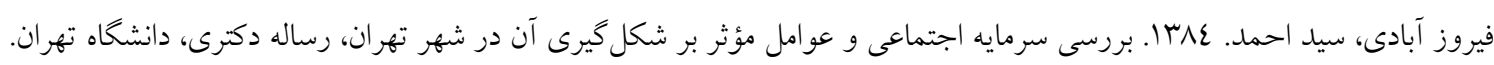

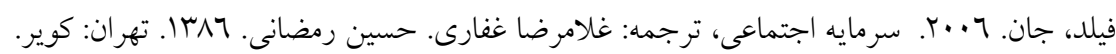

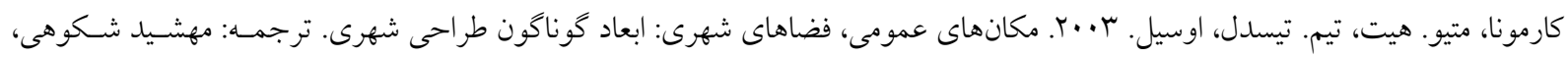

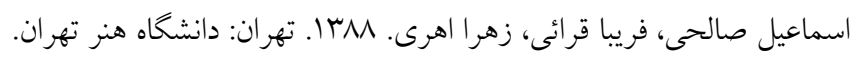

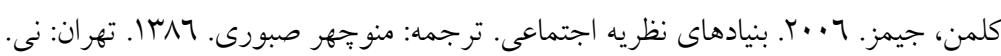

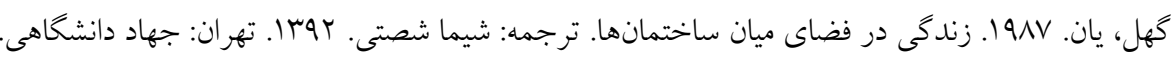

\section{منابع انكَليسى}

Adler, Paul.S. Kwon, Seok-Woo. 2002. Social Capital: Prospects for a New Concept. Academy of Management Review. 27(1): 17-40.

Barton, H. Grant, M. and Guise, R. 2003. Shaping Neighborhoods: A Guide for Health, Sustainability and Vitality. London and New York: Spon Press.

Bourdieu, P. 1985. The forms of capital. In Handbook of Theory and Research for the Sociology of Education. ed. J.G. Richardson, 241-258, New York: Greenwood.

Cabrera, J.F. 2013. New Urbanism and Selection Bias in the Formation of Social Capital. Housing Policy Debate. 23(2):376394.

Carmona, M. T. Heath, S. and Tiesdell, Oc. 2003. Public Places, Urban Spaces: The Dimensions of Urban Design. Translate by Fariba Gharaei, Zahra Ahari, Mahshid Shokouhi, Esmaeil Salehi. 2012. Tehran: Art University of Tehran. [in Persian]

Cattell, V. 2001. Poor People, Poor Places and Poor Health: The Mediating Role of Social Networks and Social Capital. Social Science \& Medicine. 52:1501-16.

Coleman, James. 2006. Foundations of Social Theory. Translated by Manouchehr Saboori. 2007. Tehran, Nei. [in Persian]

Crnic, M. 2012. Social Capital and Neighbourhood Centers in Queensland: Qualitative Case Studies of Three Neighbourhood Centers. PhD diss. Queensland University of Technology.

Field, John. 2006. Social Capital. Translated by Gholamreza Ghaffari, Hosein Ramazani. 2007. Tehran: Kavir. [in Persian]

Firouzabadi, S.A. 2006. The factors affecting the formation of social capital in Tehran, PhD diss. Tehran University. [in Persian]

Forrest, R. Kearns, A, 2001. Social Cohesion, Social Capital and the Neighbourhood. Urban Studies. 38(12): 2125-2143

Francis, J. Corti, B. Wood, L. Knuiman, A. 2012. Creating Sense of Community: The Role of Public Space, Journal of Environmental Psychology. 32: 401-409

French, S. Wood, L. Foster, S.A. Giles-Corti, B. Frank, L. Learnihan, V. 2014. Sense of Community and Its Association with The Neighborhood Built Environment. Environment Behavior. 46(6): 677-697.

19

فرهنحَ معمارى و شهرسازى اسلامى - سال ينجم، شماره دوم- پإييز و زمستان 99 
Fukuyama, F. 1997. The End of the Order. Translated by Gholamreza, Tavasolli. 2007. Tehran, Hekayat ghalam novin. [in Persian]

Fulkerson, G.M and Thompson, G.H. 2008. The Evolution of a Contested Concept: A Meta-Analysis of Social Capital Definitions and Trends, Sociological Inquiry, 78(4):536-557

Gehl, J. 1987. Life Between Buildings: Using Public Space. Translated by shima shastchi. 2013. Tehran: Tehran University. [in Persian]

Gehl, J and Svarre, B. 2013. How to Study Public Life, Translated by Karen A. Steenhard. 2014. Washington: Island Press.

Grootaert, C. Bastelaer, T.V. 2002. Understanding and Measuring Social Capital: A Multidisciplinary Tool for Practitioners, Washington D.C.: World Bank.

Holtan, M. T. Dieterlen, S.L. and Sullivan, W.C. 2014. Social Life Under Cover: Tree Canopy and Social Capital in Baltimore, Maryland. Environment \& Behavior. 46(6): 1-24

Jacobs, Jane. 1992. The Death and Life of Great American Cities, Translated by Hamidreza Parsi and Arezoo Aflatooni.2013. Tehran: Tehran University. [in Persian]

Kang, B, (2006.. Effect of Open Spaces on The Interpersonal Level of Resident Social Capital: A Comparative Case Study of Urban Neighbourhoods in Guangzhou. PhD diss. A\&M University.

Kaplan, S. 1983. A Model of Person-Environment Compatibility. Environment and Behavior. 15:311-332.

Kazmierczak, A. 2013. The Contribution of Local Parks to Neighborhood Social Ties. Landscape and Urban Planning. 109(1): 31-44.

Koohsari, M.J. Karakiewicz, J.A. Kaczynski, A.T. 2012. Public Open Space and Walking: The Role of Proximity, Perceptual Qualities of the Surrounding Built Environment, and Street Configuration. Environment and Behavior. 45(6): 706-736.

Koohsari, M. J. Mavoa, S. Villanueva, k. Sugiyama, T. Badland, H. kaczynski, A.T. Giles-Corti, B. 2015. Public Open Space, Physical Activity, Urban Design and Public Health: Concepts, Methods and Research Agenda. Health \& Place. 33: $75-$ 82.

Leyden, K. M. 2003. Social capital and built environment: The Important of Walkable Neighborhoods. American Journal of Public Health. 9: 1546-51

Lin, N. 2001. Social Capital: A Theory of Social Structure and Action. Cambridge: Cambridge University Press.

Moore, G.T. 2006. Environment, Behaviour and Society: A Brief Look at the Field and Some Current EBS Research at the University of Sydney. In Proceedings of the 6th International Conference of the Environment-Behaviour Research Association. China. May.

Perkins, D.D. and Long, D.A. 2002. Neighborhood Sense of Community and Social Capital: A Multi-level Analysis. In Psychological Sense of Community: Research, applications, and implications. ed. A. Fisher, C. Sonn, and B. Bishop, 291-318. New York: Plenum.

Pirbabaei, M.GH, Firouzabadi, A, Hojjat, I, Soltanzadeh, M. 2016. Religion and Social Capital Analysis of Social Capacities of the Islamic Society of Iran. Social Theories of Muslim. 6(1): 107-128. [in Persian]

Putnam, R. D. 1996. Who Killed Civic American? Prospect. 7(24): 66-72.

Semenza, J.A. March, T.L. 2009. An Urban Community-Based Intervention to Advance Social Interactions, Environment and Behavior. 41(1): 22-42.

Subramanian, S.V. Lochner, K. A. Kawachi, I. 2003. Neighborhood Differences in Social Capital: A Compositional Artifact or a Contextual Construct? Health \& Place. 9: 33-44.

Rogers, S. H., Halstead, J. M., Gardner, K. H. and Carlson, C. H. 2010. Examining Walkability and Social Capital as Indicators of Quality of Life at The Municipal and Neighborhood scales. Applied Research Quality of Life. 6(2): 201-213.

Uphoff, N. 2000. Understanding Social Capital: Learning from the Analysis and Experience of Participation. In Social Capital: A Multifaceted Perspective. ed. Partha Dasgupta and Ismail Serageldin. 215-249. Washington D.C.: World Bank.

Vemuri, A.W. Grove, G.M. Wilson, M.A. Burch, W.R. 2011. A Tale of Two Scales: Evaluating the Relationship Among Life Satisfaction, Social Capital, Income, and the Natural Environment at Individual and Neighborhood Levels in Metropolitan Baltimore. Environment and Behavior. 43(1): 3-25.

Weller, S. Bruegel, L. 2009. Children's 'Place' in the Development of Neighbourhood Social Capital. Urban Study. 46(3): 629643.

Wood, L. 2006. Social Capital, Neighbourhood Environment and Health: development of measurement tools and exploration of links through qualitative and quantitative research. PhD diss. University of Western Australia.

Wood, A. Giles-Corti, B. 2008. Is There a Place for Social Capital in The Psychology of Health and Place?. Journal of Environmental Psychology. 28:154-163.

Wood, L. Shannon, T. Bulsara, M. Pikora, T. McCormack, G. Giles-Corti, B. 2008. The anatomy of the safe and social suburb: An exploratory study of the built environment, social capital and residents' perceptions of safety. Health \& Place. 14: $15-31$.

Wood, A. Giles-Corti, B. Bulsara, M. 2012. Does Social Capital Vary with Neighbourhood Design. Urban Studies Research. 2012: 1-11. 